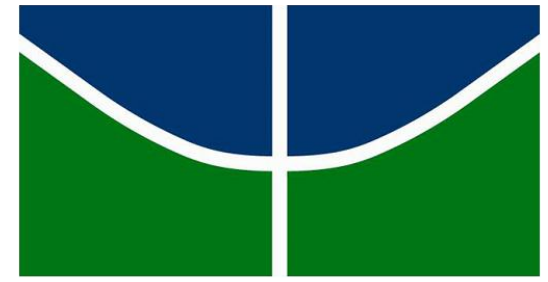

Universidade de Brasília - UnB

Instituto de Ciências Sociais - ICS

Departamento de Antropologia - DAN

\title{
"Simulando vidas": uma etnografia do Programa Minha Casa Minha Vida e o financiamento habitacional
}

Barbara Marciano Marques

Brasília, 2018 
Barbara Marciano Marques

\title{
"Simulando vidas": uma etnografia do Programa Minha Casa Minha Vida e o financiamento habitacional
}

\begin{abstract}
Monografia apresentada ao Departamento de Antropologia da Universidade de Brasília como um dos requisitos para obtenção do grau de bacharel em Ciências Sociais, com habilitação em Antropologia.
\end{abstract}

Orientadora: Profa. Dra. Antonádia Monteiro Borges

Brasília, 2018 
Universidade de Brasília - UnB

Instituto de Ciências Sociais - ICS

Departamento de Antropologia - DAN

\title{
"Simulando vidas": uma etnografia do programa Minha Casa Minha Vida e o financiamento habitacional
}

\begin{abstract}
Monografia apresentada ao Departamento de Antropologia da Universidade de Brasília como um dos requisitos para obtenção do grau de Bacharel em Ciências Sociais com habilitação em Antropologia.
\end{abstract}

Barbara Marciano Marques

BANCA EXAMINADORA

Prof ${ }^{a}$. Dra. Antonádia Monteiro Borges - Departamento de Antropologia - UnB

Prof $^{a}$. Dra. Cristina Patriota de Moura - Departamento de Antropologia - UnB

Prof ${ }^{a}$. Ma. Stella Zagatto Paterniani - Departamento de Antropologia - UnB

Brasília, 2018 


\begin{abstract}
A CASA
Vinicius de Moraes

Rio de Janeiro , 1970
\end{abstract}

Era uma casa

Muito engraçada

Não tinha teto

Não tinha nada

Ninguém podia

Entrar nela não

Porque na casa

Não tinha chão

Ninguém podia

Dormir na rede

Porque a casa

Não tinha parede

Ninguém podia

Fazer pipi

Porque penico

Não tinha ali

Mas era feita

Com muito esmero

Na Rua dos Bobos

Número Zero.

"Why has a state whose proclaimed motive is to foster development failed to help the large number of people who still live in dire poverty?"

(Akhil Gupta) 


\section{Agradecimentos}

Agradeço à Edite e João, meus pais, e a Isadora, minha irmã, que nunca podaram meus sonhos e me permitiram fazer minhas próprias escolhas sempre me dando apoio,

agradeço a tia Lazara, tio Lazaro e toda família pelo suporte oferecido nos anos de universidade,

aos meus padrinhos e madrinhas pela confiança depositada,

à minha avó pelas orações.

Agradeço também pelos girassóis que floresceram em meu caminho durante os anos de graduação, Isa Ribeiro, Isa Livingstone, Laura, Brenda, Babi, Sarah, Camila, Isabelle, Geovanna, Gabi, Mari e Jéssica,

agradeço ao José pelos deliciosos cafés que sempre acabam em antropologia,

à Natália e Matheus pelas leituras e discussões,

à primeira pessoa que me ofereceu um ombro amigo em sociais Vini Venâncio.

Agradeço a querida professora Antonádia por me mostrar a beleza da antropologia e me aceitar como orientanda, acompanhando-me todos esses meses,

e por nossos iluminados encontros,

às colegas do GESTA pelas incríveis leituras e discussões.

Agradeço às professoras do departamento de antropologia da UnB pelas excelentes trocas e aprendizados,

à Rosa por toda sua dedicação e comprometimento com as alunas do Dan.

Agradeço a querida professora Soraya e a revista Anuário Antropológico por me fazerem descobrir uma nova versão de mim mesma,

às professoras Margarita e Éverton do departamento de Saúde Coletiva, que por vezes me fizeram pensar "fora da caixinha".

Agradeço a todas as pessoas que cruzaram minha trajetória e de alguma forma influenciaram no que me tornei hoje.

Agradeço às Professoras Cristina Patriota e Stella Paterniani por aceitarem fazer parte da banca,

à Universidade de Brasília pelas aulas, bolsas, projetos e vivências únicas que pude experiementar,

E por fim agradeço à Leide e Eliene, mulheres sem as quais este trabalho não seria possivel. 


\section{Resumo}

Esta monografia de conclusão de graduação tem como proposta apresentar uma reflexão sobre o financiamento habitacional e o Programa Minha Casa Minha Vida em contextos de pouca solvência financeira. Buscamos aqui contar as histórias de Leide, proprietária de imobiliária e corretora de imóveis, e seus clientes, que vêem no financiamento habitacional promovido pelo programa à única saída para aquisição da casa própria. O texto foi dividido em duas partes, a primeira focada em Leide e os processos de financiamento que ocorrem em sua imobiliária, na segunda o foco se direciona a Eliene, funcionária de Leide que financiou um imóvel através do programa há alguns anos e agora trabalha com o financiamento. Através dessas histórias tentaremos compreender um pouco do mecanismo de financiamento habitacional e a construção da figura do beneficiário por meio das comprovações apresentadas a Caixa Econômica Federal.

Palavras-chave: Programa Minha Casa Minha Vida, financiamento habitacional, burocracia 


\section{Sumário}

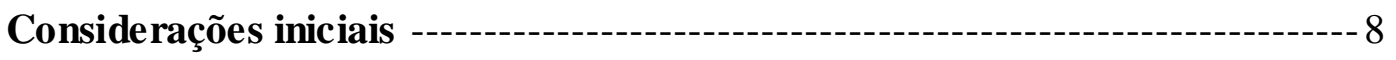

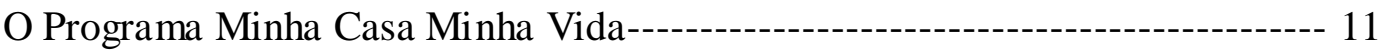

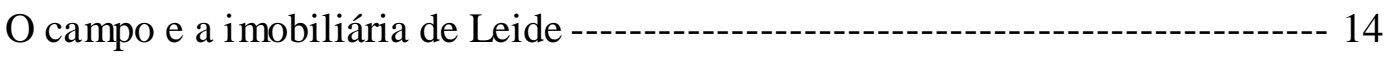

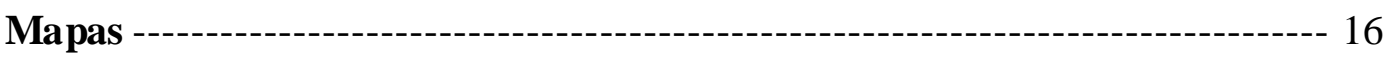

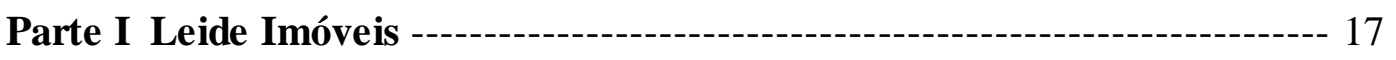

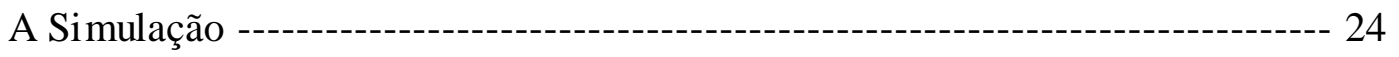

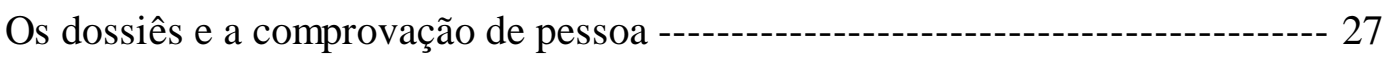

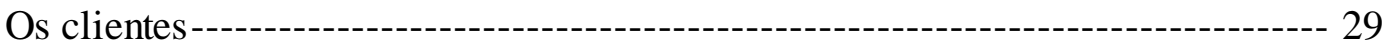

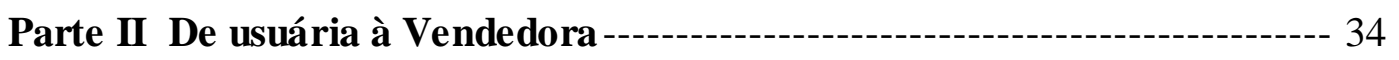

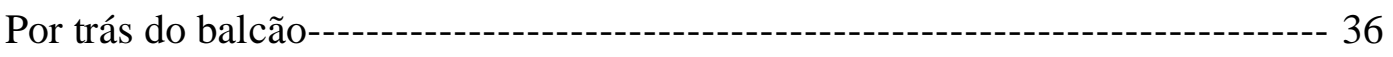

"Meus clientes sonham com algo muito melhor" ----------------------------------- 38

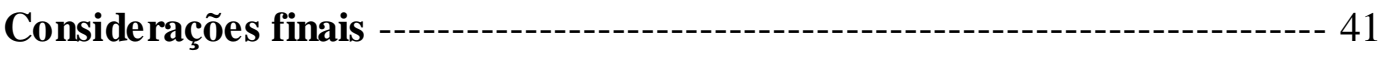

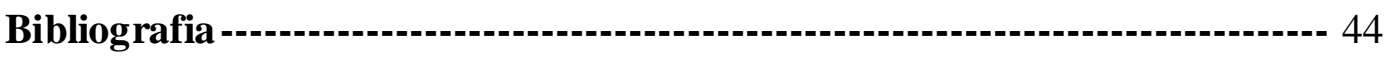




\section{Considerações iniciais}

Em uma tarde de outubro de 2016 eu estava voltando da UnB para casa por um trajeto diferente do que estava acostumada, sempre caminhei até a L2 para pegar o ônibus que vai direto à W3. Naquele dia, em virtude do calor e da baixa umidade do tempo, resolvi pegar o 110, ônibus que vai da UnB até a Rodoviária do Plano Piloto e da rodoviária pegar outro até a $\mathrm{W} 3^{1}$.

Nessa época eu havia começado um projeto de iniciação científica com a professora do departamento de antropologia da Universidade de Brasília, Antonádia Borges, em que buscávamos compreender o acesso de mulheres à moradia através da política pública habitacional programa Minha Casa Minha Vida. Estávamos muito no início, ainda fazendo o levantamento de bibliografia para trabalhar o assunto.

Desci do ônibus na Rodoviária do Plano Piloto e no caminho para a plataforma do 116, perto da escadaria que dá acesso à parte de cima da rodoviária avisto um grupo de homens e mulheres uniformizados nas cores amarelo e azul, com uma plaquinha nas costas com o símbolo do Programa Minha Casa Minha Vida ${ }^{2}$, segurando algumas fichas, que logo em seguida descobri serem fichas cadastrais, apoiadas em uma prancheta. Era um grupo de corretores imobiliários que abordavam os passageiros da rodoviária oferecendo os serviços do programa. Acreditei estarem fazendo essa abordagem na Rodoviária, em virtude da quantidade de pessoas que passam por ali diariamente. A grande coincidência foi eu passar na Rodoviária exatamente no dia em que eles estavam em "ação". Achei o fato bastante curioso.

Aproximei-me do grupo e um homem logo me abordou e perguntou meu nome. Respondi e ele ofereceu os serviços que estavam prestando. Sem intencionar, tornei-me de imediato alguém com intenção de financiar um imóvel. Quando dei por mim, revidei, perguntando-lhe quais eram os documentos necessários e as condições para o financiamento. O corretor me informou que eles precisavam "só" das minhas informações pessoais básicas como data de nascimento, CPF e renda para dar início a uma simulação. Se eu tivesse o crédito "aprovado" era "só" escolher a casa dentre os imóveis que eles tinham disponíveis.

\footnotetext{
${ }_{2}^{1}$ L2 e W3 são vias expressas de Brasília

${ }^{2}$ Abreviação PMCMV
} 
Ainda sem entender o que significava cada uma das categorias utilizadas por ele, agradeci pelas informações e, por fim, contei meu interesse no Programa Minha Casa Minha Vida. Ele prontamente se colocou à disposição para tirar qualquer dúvida que eu tivesse sobre o programa. Trocamos telefones.

A compreensão deste evento, que passaria desapercebido aos meus olhos e a de qualquer outra pessoa que estivesse de passagem por ali sem interesse no Programa Minha Casa Minha Vida, seja como pesquisadora ou como compradora, só ocorreu de fato após meses de leitura e trabalho de campo. Não com o solícito corretor que aparece na página acima, pois a pesquisa acabou tomando um rumo diferente, mas com outras pessoas, muito especialmente com a corretora Leide, companheira de pesquisa.

Nas próximas páginas compartilharei minha curta experiência trabalhando em sua imobiliária em Planaltina-GO no primeiro semestre de 2017. No período, busquei conhecer de perto o mundo das transações imobiliárias, financiamento e habitação. Agradeço imensamente a Leide, proprietária da imobiliária, corretora de imóveis e correspondente Caixa Aqui que me deixou ser sua "secretária pessoal" e confidente, aguentando os meus cafés de curar ressaca e ignorância a respeito dos processos imobiliários.

Por ora, antes de chegar até Leide e seu trabalho, o que nos deve chamar atenção é a "facilidade inicial" de se adquirir uma habitação através do PMCMV, como propalada pelo grupo com quem encontrei na rodoviária. O que segundo o corretor, era "só" aguardar o resultado da simulação, "mais" aprovação do crédito para o cliente e, por fim, escolher dentre as casas disponíveis na imobiliária.

Esta cadeia causal demasiadamente sem percalços me fez perguntar onde estava a espera nas listas? As pessoas que eu conhecia até aquele momento, que conseguiram o financiamento habitacional pelo programa passaram meses, algumas até anos, esperando a liberação da lista de contemplados pelo programa e isso após um árduo processo de comprovação dos requisitos exigidos pelo PMCMV, até tornarem-se aptas ao benefício.

A etnografia de Borges (2003) sobre o Recanto das Emas ${ }^{3}$ foi de grande inspiração para este trabalho. Seu livro "Tempo de Brasília", nos mostra a dura

\footnotetext{
${ }^{3}$ Região administrativa do Distrito Federal
} 
realidade de pessoas que dependem das listas para receber um lote (BORGES, 2003). Assim como a distribuição de lotes, a distribuição de casas pelo programa de habitação no Distrito Federal dispõem de uma série de critérios, um deles é morar no DF nos últimos cinco anos, ou seja comprovar o "Tempo de Brasília".

Um dos programas de acesso à moradia promovidos pelo Governo do Distrito Federal é o Morar Bem ${ }^{4}$, que vincula-se ao Programa Minha Casa Minha Vida por utilizar o subsídio governamental destinado a promoção de habitações. Ao digitar as palavras Morar Bem na caixa de pesquisa do Facebook ${ }^{5}$ aparece uma lista de grupos e redes de pessoas inscritas no programa, que utilizam a rede social para trocar informações, lamentos e fazer propaganda do PMCMV. Da observação de suas interações, outra questão surge: como explicar a proliferação de habitações e conjuntos habitacionais por todo o entorno de Brasília ao mesmo tempo em que aparentemente os contemplados pelo Morar Bem diminuem?!

Na rodoviária do Plano Piloto ou no Facebook, é possível dizer que o que se faz é propaganda, em dois sentidos. Por um lado, faz-se propaganda de uma iniciativa governamental para promoção de habitação própria. Por outro, divulgam-se as imobiliárias que anunciam e intermediam a aquisição de habitações passíveis de serem financiadas pelo PMCMV. Em suma, nos dois casos, além da casa, vende-se também um financiamento.

O Morar Bem corresponde a uma iniciativa governamental que prioriza as faixas mais baixas de renda atendidas pelo PMCMV. As imobiliárias, desde que o crédito do cliente/beneficiário seja aprovado pelo banco e que possuam em seu estoque imóveis cujo valor caiba dentro do modelo de financiamento aprovado pela simulação, podem selar as vendas/aquisições. Ainda que as imobiliárias que trabalhem com o tipo de financiamento oferecido pelo programa possam atuar em todas as faixas de renda, neste trabalho trataremos da aquisição financiada de uma casa no que se conhece como "faixa

\footnotetext{
${ }^{4}$ Proposta do governo do Distrito Federal; "O eixo Morar Bem, vinculado ao Programa Minha Casa, Minha Vida, do go verno federal, tem transformado o sonho da casa própria em realidade. A ação é voltada para famílias com renda bruta de até 12 salários mínimos. Esse eixo visa a construção de unidades habitacionais no Distrito Federal. A proposta é ofertar moradias com infraestrutura urbana, como abastecimento de água, esgoto sanitário, energia elétrica, iluminação pública, instalações telefônicas, redes de drenagem de águas pluviais, pavimentação asfáltica e, equipamentos públicos, como escolas, postos de saúde e de polícia."

(Trecho extraído de: http://www.codhab.df.gov.br/pagina/1. Acessado em 29/09/2017)

${ }^{5}$ rede social virtual
} 
1,5"de atuação do Programa Minha Casa Minha Vida, em suma discutiremos o financiamento habitacional em contextos de pouca solvência financeira.

Para melhor compreender os fatos que serão apresentados nas páginas seguintes, é necessário uma explicação sobre a habitação social no Brasil e as diretrizes de atuação do Programa Minha Casa Minha Vida.

\section{O Programa Minha Casa Minha Vida}

A história da habitação no Brasil é marcada pela produção de moradia privada e para aluguel. Salvo em alguns períodos históricos em que houve promoção estatal de habitação social, como na ditadura de Vargas e durante a ditadura Militar. Em trabalho sobre as origens da habitação social no Brasil, Nabil Bonduki, analisa a intervenção estatal na questão da habitação de interesse social no Brasil (BONDUKI, 1994).

O período Vargas trata do primeiro momento na história do Brasil em que o Estado passa a intervir tanto no processo de produção como no mercado de aluguéis, influenciado pela crescente e recente industrialização do país. A moradia até então era deixada as livres forças de mercado. Em seu trabalho Bonduki nos conta que:

"As medidas de Vargas em relação à questão habitacional estiveram o decreto lei do inquilinato em 1942 que visava regulamentar as ações entre locadores e inquilinos, a criação das carteiras prediais dos Institutos de Aposentadoria e Previdência e da Fundação da Casa Popular, que deram início à produção estatal de moradias subsidiadas e, em parte, viabilizaram o financiamento da promoção imobiliária, e o Decreto-Lei n. ${ }^{\circ} 58$, que regulamentou a venda de lotes urbanos a prestações" (BONDUKI, 1994, p. 1).

As medidas de Vargas estavam de comum acordo com sua forma de governo que objetivava a manutenção e regulamentação das relações entre trabalho e capital e garantir as condições de trabalho assalariado. A lei do inquilinato que em 1942 congelava os aluguéis auxiliou os trabalhadores assalariados, no entanto a grande parcela de imigrantes que chegou ao Brasil na época se viu sem moradia, por não conseguirem encontrar habitações que cabiam em seus baixos salários. Outro fator que colaborou para o declínio das iniciativas de Vargas foi a ocorrência da Segunda Guerra 
Mundial que teve como consequêcia o aumento das periferias e da autoconstrução (BONDUKI, 1994).

Em 1964 após o golpe militar a reforma habitacional foi considerada de alta prioridade. A reforma idealizada no período se baseava na promoção da habitação própria financiada e utilizou dessa "propaganda" para promover o governo autoritário. O principal objetivo dessa política habitacional transformar os trabalhadores assalariados em proprietários de suas habitações. A principal medida foi a criação do Banco Nacional de Habitações (BNH), do Sistema Financeiro de Habitação (SFH) e do Fundo de Garantia por Tempo de Serviço (FGTS) (MELO, 2014). O Banco Nacional de Habitação $(\mathrm{BNH})$ era o principal órgão da política habitacional urbana do país, durante o século XX, sua função prioritariamente era orientar disciplinar e controlar o Sistema Financeiro da Habitação (SFH) para promover a construção e a aquisição da casa própria (MOTTA, 2011).

As políticas de habitação no Brasil foram implementadas para atender interesses privados, mais do que o bem-estar da população. Ao longo do século XX assistiu-se uma forte articulação entre o Estado e o setor produtivo, o que garantiu a priorização de políticas habitacionais voltadas para o crescimento econômico, tal como a política de direito à moradia, citada anteriormente, até então estruturada através do BNH (KLINTOWITZ, 2016, p.2). O contexto de elaboração do PMCMV, anos após a extinção do $\mathrm{BNH}$, não foi diferente, teve em suas origens e diretrizes a preocupação com crescimento econômico e em não deixar o setor produtivo da construção civil entrar em colapso devido à crise vigente na época, ao invés do direito à moradia.

O Programa Minha Casa Minha Vida surgiu como medida de reestruturação do setor produtivo brasileiro diante da crise do subprime, hipotecária, ocorrida no ano de 2007. Através do programa o governo visualizou uma maneira de socorrer o setor produtivo da construção civil e evitar o aprofundamento da crise (KLINTOWITZ, 2016, p.3). As diretrizes de funcionamento do PMCMV foram elaboradas pela casa civil e ministério da fazenda, em diálogo com os setores imobiliários e da construção civil.

$\mathrm{Na}$ época de lançamento do programa cerca de $90 \%$ do déficit habitacional ${ }^{6}$ se concentrava em famílias com rendimentos somados em até três salários mínimos

\footnotetext{
6 "Segundo o Ministério das Cidades (2011), o conceito de déficit habitacional está ligado diretamente às deficiências do estoque de moradias. Engloba aquelas sem condições de ser habitadas e que devem ser repostas, incluindo ainda a necessidade de incremento do estoque de moradias em função da coabitação
} 
(HIRATA,2009). Utilizando recursos do FGTS (Fundo de Garantia por Tempo de Serviço), SBPE (Sistema Brasileiro de Poupança e Empréstimo), FAR (Fundo de Arrendamento Residencial), OGU (Orçamento Geral da União) e FNHIS (Fundo Nacional de Habitação de Interesse Social), em suas fases 1 (2009- 2011), 2 (20112013) e 3 (2016- 2018), o programa ofereceu subsídios a três faixas de renda familiar: Subsídios integrais a famílias cujos rendimentos somados atingem o valor de três salários mínimos (faixa 1); Subsídios parciais aquelas cuja renda mensal fica entre três a dez salários mínimos (faixa 2 e 3). Essas últimas são consideradas pela literatura como "faixas de mercado", porque supõe-se que poderiam teoricamente entrar no mercado imobiliário sem o subsídio estatal (SILVA, 2016). Após alguns anos de funcionamento o programa passou a considerar as "quatro" faixas de renda mostradas no quadro abaixo;

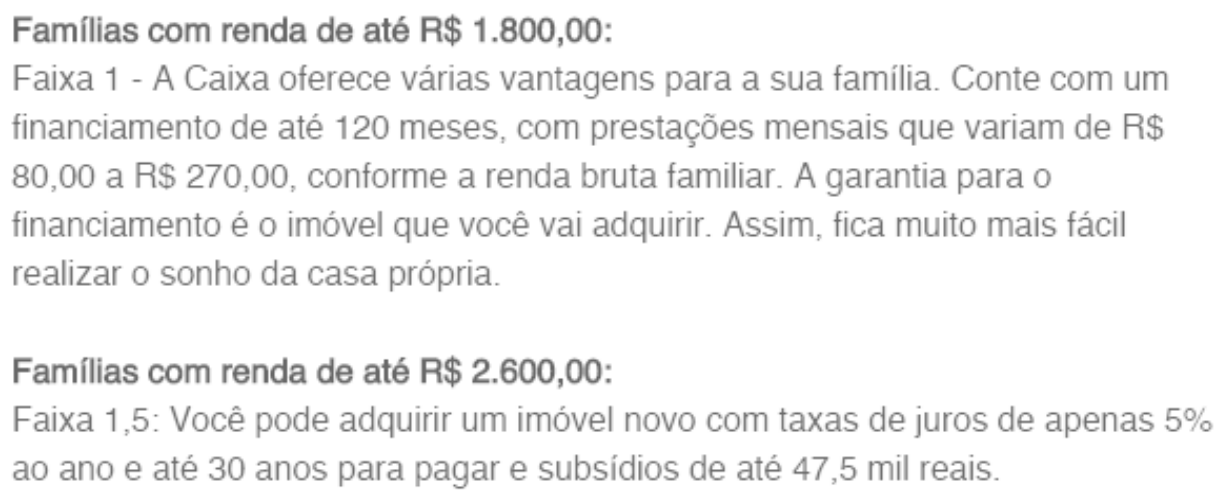

Famílias com renda de até $\mathrm{R} \$ 4.000,00$ :

FAIXA 2: Se sua família tem renda bruta de até $R \$ 4.000,00$, você se encaixa nesta faixa do Programa Minha Casa Minha Vida e pode ter subsídios de até R\$ $29.000,00$.

Famílias com renda de até $\mathrm{R} \$ 7.000,00$ :

FAIXA 3: Para famílias com renda bruta de até $\mathrm{R} \$ 7.000,00$, a faixa 3 do Programa Minha Casa Minha Vida oferece taxas de juros diferenciadas em relação ao mercado para você conquistar uma casa própria.

Fai xas de Renda

familiar forçada (casos em que mais de uma família mora na mesma casa), o adensamento excessivo (quando mais de três pessoas dividem o mesmo quarto) ou ônus excessivo de aluguel (quando uma família compromete mais de $30 \%$ de sua renda com aluguel)" (JÚNIOR; DUTRA; LOPES \& RODRIGUES, 2014, p. 2) 
As faixas de renda são determinadas a partir da comprovação de renda formal, através da apresentação de contracheques, e informal, pela apresentação de comprovantes de prestação de serviços e transações bancárias. A faixa 1 é onde se encontra o maior número de pessoas sem habitação própria e que supostame nte seriam foco do programa, essa é a faixa atendida pelo Morar Bem. A faixa $1,5^{7}$ localiza pessoas que não conseguem comprovar renda suficiente para faixa 2 e conseguem comprovar renda acima do valor determinado para faixa 1. As faixas 2 e 3 são as quais existem um mercado voltado a produção de habitações, podendo comprar um imóvel na planta financiar por até 30 anos.

Tentaremos demonstrar ao longo das páginas que se sequem que todas as faixas de renda atendidas pelo PMCMV são "faixas de mercado", e que ao adquirir a casa própria adquire-se também um financiamento próprio. No entanto, para conseguir um financiamento através do programa, não basta estar dentro das faixas atendidas, é necessário combinar a isso uma série de outras "aprovações" e principalmente encontrar um imóvel no valor do financiamento aprovado. Esse é o fator que impede as imobiliárias de venderem imóveis às primeiras faixas de renda, o que leva a população "baixa renda" a ter esperança nas iniciativas/listas governamentais (Morar Bem).

Neste trabalho contaremos a rotina da corretora Leide e seus clientes no que diz respeito aos processos financiamento imobiliário, procurando pensar o direito a moradia adequada e a forma de acesso a esse direito promovida pelo programa habitacional Minha Casa Minha Vida. Rolnik (2015) uma das autoras com quem dialogamos propõe a ideia de que o PMCMV criou um mercado de habitações, aproveitando-se do grande déficit habitacional enfrentado pelo Brasil e a ambição das camadas populares pela casa própria. Esse processo se configuraria como a nova forma de expansão do capital financeiro, que se apropria de um discurso em que o mercado pode não somente regular a alocação de moradia, como fazer a distribuição de recursos de forma mais racional (ROLNIK, 2015). Essa premissa teria levado as políticas públicas de habitação a abandonar os conceitos de moradia como um bem social e de cidade como um artefato público (Idem), e a investir na construção de casas para fins de mercado.

\footnotetext{
${ }^{7}$ Faixa que insere as pessoas que mais procuram a imobiliária de Leide.
} 
Conheci Leide através de Antonádia, minha orientadora, que por sua vez a conheceu através de Iara Conceição da Silva, diarista que trabalha em sua casa, que por fim era cliente de Leide, e havia financiado uma casa em sua imobiliária. Por meio dela conseguimos o contato de Leide e perguntamos se poderíamos entrevistá-la, e Leide sempre disposta, prontamente nos concedeu a entrevista e nos ajudou ao longo da pesquisa.

Dessa maneira tivemos o primeiro contato com Leide, em uma manhã de março desloquei-me até Planaltina- GO para conhecê-la. Na imobiliária Leide contou sobre seu trabalho e as dificuldades que estava enfrentando sem uma de suas funcionárias, que há poucos dias tinha demitido. Mais uma vez a coincidência se fez presente, e eu me ofereci para trabalhar com ela até que outra funcionária fosse contratada. Após algumas negociações ela topou o combinado e aceitou-me como sua aprendiz, esta monografia de graduação é fruto desse aprendizado.

Planantina de Goiás ou "Brasilinha" como é conhecida popularmente desenvolveu-se juntamente com a construção de Brasília. Encontramos poucos registros da história da cidade na internet, mas ao que parece na demarcação do espaço que seria o Distrito Federal, a cidade de Planaltina ficou dividida em duas, o que seria hoje Planaltina- DF e Planaltina- GO.

A parte da cidade de Planaltina, que ficou no estado de Goiás, precisou reconstruir-se e, assim como Brasília, foi uma cidade planejada, por isso o apelido de "Brasilinha". As pessoas diziam que estavam construindo uma Brasília no Distrito Federal, e uma Brasilinha no Estado vizinho, há $60 \mathrm{~km}$ da nova capital. No entanto a conexão com Brasília não é só essa, Planaltina de Goiás é uma das cidades que compõem a RIDE $\mathrm{DF}^{8}$.

\footnotetext{
8 "A Região Integrada de Desenvolvimento do Distrito Federal e Entorno (RIDE/DF) foi criada pela Lei Complementar $\mathrm{n}^{\circ}$ 94, de 19 de fevereiro de 1998 e regulamentada pelo Decreto $\mathrm{n}^{\circ} 2.710$, de 04 de agosto de 1998, alterado pelo Decreto ${ }^{\circ} 3.445$, de 04 de maio de 2000. A RIDE tem como objetivo articular e harmonizar as ações administrativas da União, dos Estados e dos municípios para a promoção de projetos que visem à dinamização econômica e provisão de infraestruturas necessárias ao desenvolvimento em escala regional." Texto extraído de http://www.mi.gov.br/regioes_integradas_df_rides último acesso em 28/01/2018
} 
A relativa proximidade entre as duas cidades, Brasília e Brasilinha, promove um grande fluxo de pessoas, que buscam ou prestam serviços no Distrito Federal, fazendo com que Planaltina-Go seja considerada cidade dormitório para parte da população que utiliza a cidade "apenas para dormir". O baixo preço dos terreno e as "facilidades" promovidas pelo Programa Minha Casa Minha Vida tornaram a cidade atrativa aos construtores e também a população que busca moradia própria com preço mais acessível.

Dividimos a monografia em duas partes. A primeira contará de Leide e das atividades que ocorrem na imobiliária. Leide é peça fundamental na vida daqueles que desejam adquirir ou vender um imóvel através do financiamento habitacional da Caixa Econômica Federal. As pessoas que a procuram têm ciência de sua sabedoria, responsabilidade e comprometimento na realização de seu trabalho. Demonstraremos aqui o esforço de Leide em fazer com que seus clientes compreendam as regras do jogo imobiliário, para assim conseguirem ganhar a partida, a casa.

A segunda parte contará a história de Eliene, funcionária contratada por Leide. Eliene vive as experiências por dentro e fora do balcão, ela é ao mesmo tempo beneficiária e "beneficia" outras pessoas com o financiamento habitacional. Eliene financiou uma habitação com Leide anos antes de trabalhar na imobiliária e este capítulo trata do antes e depois de Eliene, da compreensão dos processos imobiliários por uma ótica de "dentro e fora". 


\section{Mapas:}

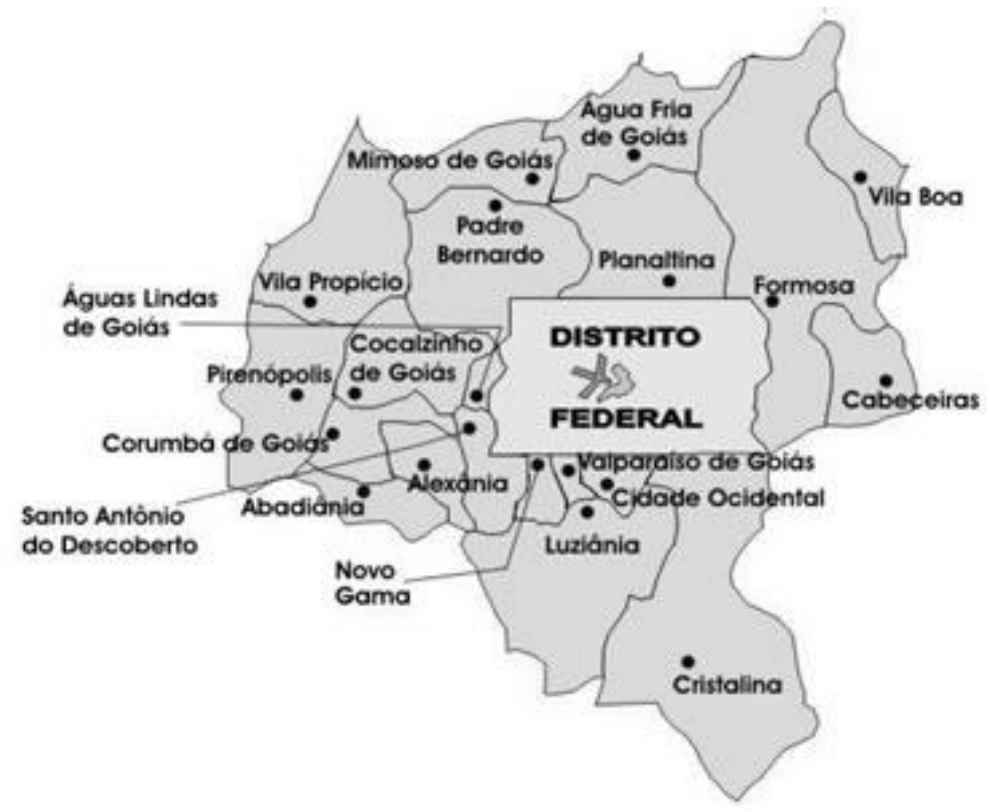

Região Integrada de Desenvolvimento do Distrito Federal e Entorno (RIDE/DF)

Google Maps de Asa Norte, Brasília- DF, 70297-400 a Planaltina, GO

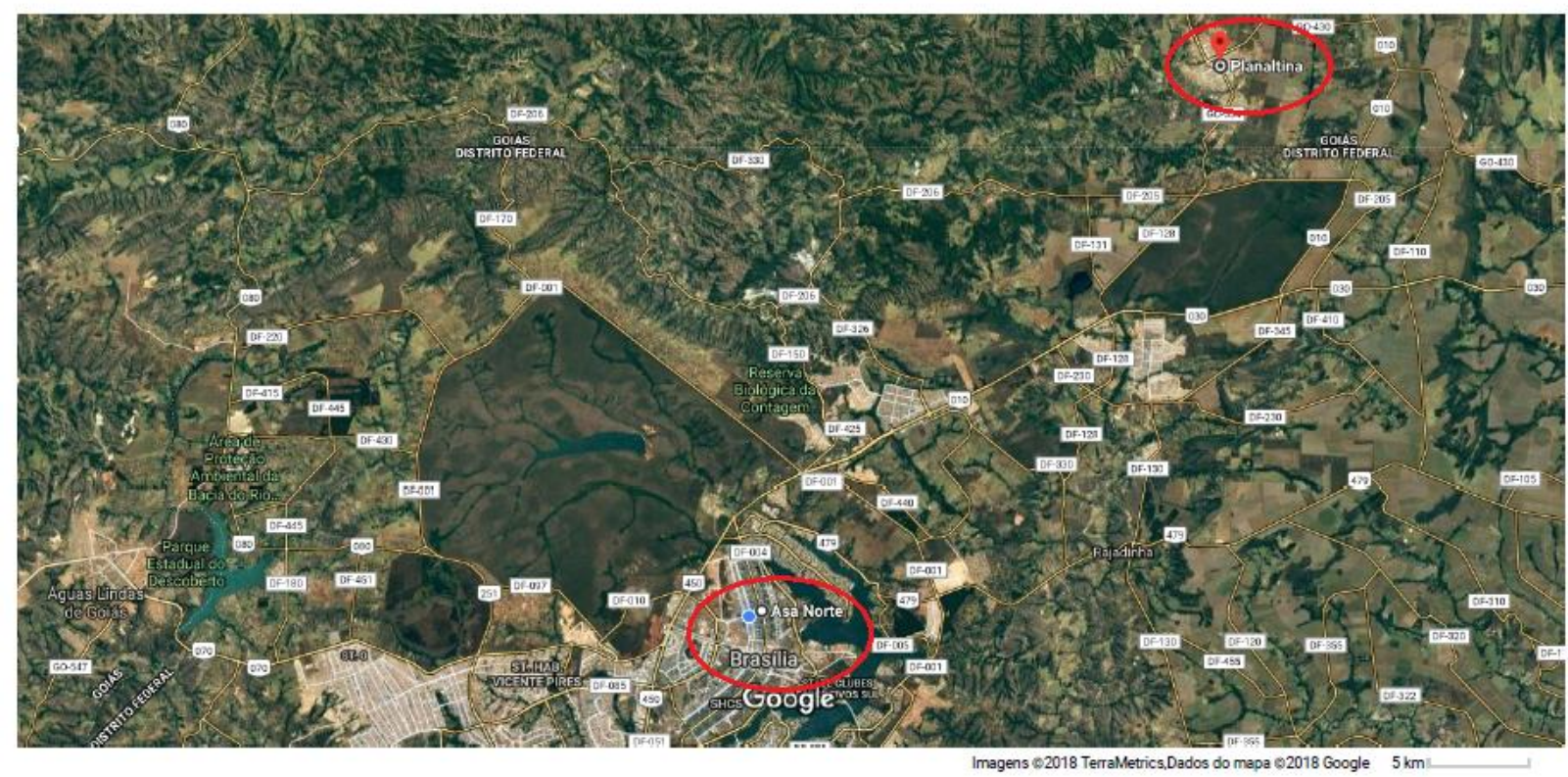

Plano Piloto e Planaltina GO 


\section{Parte I- Leide Imóveis}

Leide: a questão da dívida, ela é... assim no meu caso aqui como eu instruo muito bem o meu cliente o risco ele é pequeno, porque ele sai daqui com toda uma consciência que se ele atrasar três prestações a casa dele já vai pra processo de retomada, ele já sai daqui com a consciência de que ele não deve atrasar a prestação e ele... eu tento colocar uma prestação dentro das possibilidades mínimas dele, hoje eu posso pagar Mil, "mas e no aperto quanto você pode?" "eu posso $\mathrm{R} \$ 500,00 "$ então a gente precisa trabalhar aqui, porque riscos acontecem, tem o risco do desemprego, tem o risco da crise, tem o risco de ficar doente, tem o risco de um acidente, então são riscos que acontecem, só que eu tento minimizar eles muito...

(Transcrição de entrevista realizada no dia 24/03/2017)

O sol ainda estava tímido quando peguei o ônibus em direção a Planaltina- GO, que se localiza há $60 \mathrm{~km}$ do Plano Piloto. Até lá são mais ou menos uns 60 minutos de viagem, grande parte dos passageiros, inclusive eu, aproveitavam a longa hora para dar um cochilo até o destino. A maioria deles eram trabalhadores noturnos, que deixavam seus postos após uma longa noite e retornavam para suas casas. Eu fazia o caminho inverso. Às vezes nos (des) encontrávamos novamente no ônibus das $17 \mathrm{~h}$, eu voltando para casa e eles para o trabalho.

Cheguei à imobiliária de Leide quando as portas ainda estavam baixas. Não tardou para seu funcionário chegar. Fui logo me apresentando e dizendo que passaria alguns dias com Leide para acompanhar seu trabalho como corretora e com o PMCMV. Ele disse para que eu aguardasse. Leide chegou logo em seguida, exausta. Enquanto seu funcionário organizava a loja, ela me chamou para conversar na cozinha.

A imobiliária de Leide localiza-se em uma das avenidas comerciais de Planaltina-GO, fica próxima a bancos, ao fórum municipal e é cercada por lojas. A visão que temos da entrada é a recepção, ao lado da recepção dois escritórios, um ao lado do outro. O primeiro era destinado aos funcionários e aos arquivos, pastas com 
documentações dos imóveis de aluguel. Ao entrar no cômodo, nos chama atenção os quadros com as chaves dos imóveis que estão sob responsabilidade de Leide, seja para venda ou aluguel. A cozinha onde sentamos para tomar café e conversar se localizava aos fundos, depois dos escritórios.

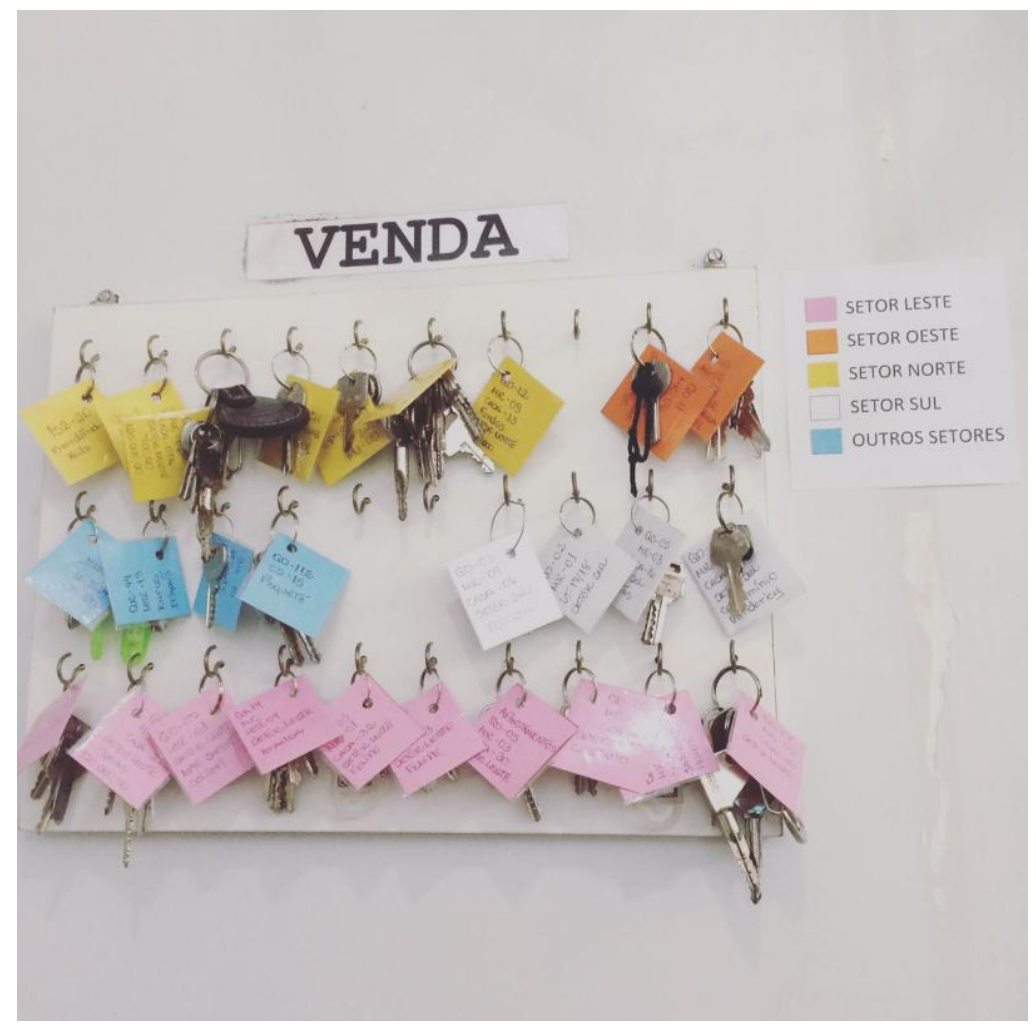

Quadro de chaves

Leide com uma expressão visivelmente cansada contou-me que tinha aproveitado o feriado do início da semana para descansar, não estava conseguindo dormir e na tentativa de pegar no sono tomou alguns remédios, que só fizeram efeito um dia depois e por esse motivo estava sonolenta. Em nossa conversa, perguntou quais eram os meus objetivos na imobiliária e como poderia me ajudar na pesquisa. Informei a ela que meu interesse estava em compreender como as beneficiárias do programa minha casa minha vida experimentavam a política pública, como acontecia o acesso ao programa, ao financiamento e por fim a moradia.

Leide trabalha com a venda de imóveis há mais de 17 anos. Começou como funcionária de uma das imobiliárias pioneiras em Planaltina- GO. Quando um dos sócios daquela imobiliária resolveu abrir um novo escritório, ela tomou conta do novo 
empreendimento: pegou a unidade "crua", como ela mesma diz, e aprendeu a trabalhar. Leide entrou no ramo imobiliário antes do programa Minha Casa Minha Vida existir. Em sua loja trabalha com muitos tipos de financiamento oferecidos pela Caixa Econômica Federal, além dos serviços Caixa Aqui ${ }^{9}$.

Caixa aqui é uma empresa conveniada junto a Caixa Econômica Federal e atua como uma extensão da instituição. Antes de tornar-se Caixa Aqui, Leide dependia da agência da $\mathrm{CEF}^{10}$ para realizar os procedimentos exigidos pelo PMCMV, como por exemplo, o cadastramento de clientes. Visando dar agilidade aos processos de financiamento habitacional e do PMCMV a Caixa Econômica desenvolveu o serviço Caixa Aqui, modelo implantando nas empresas em convênio com a caixa, como é o caso de Leide. Antes disso Leide atuava como pessoa física, após a implementação do Caixa Aqui tornou-se pessoa jurídica para se integrar ao novo sistema, passou por cursos de capacitação e também teve que adequar e padronizar sua empresa ao modelo físico exigido pelas normas da CEF. Os correspondentes Caixa Aqui são remunerados pelo convênio e de acordo com sua produção, no entanto, arcam com os custos dos processos, pagando impostos sobre toda remuneração e fluxo de trabalho.

Durante meu primeiro dia, Leide me deu instruções básicas de como funcionava seu trabalho na loja. Apresentou-me o manual, um passo a passo que ela mesma tinha elaborado para facilitar o trabalho de seus funcionários na utilização dos sistemas eletrônicos da Caixa. O manual estava encadernado e continha uma série de rasuras e acréscimo de informações à caneta. Ao notar meu interesse nesses detalhes Leide informou que o sistema da Caixa mudava com frequência e que sempre precisava atualizar o manual. Em uma de suas reflexões, Bruno Latour, nos conta de um tipo de comunicação chamada duplo-clique, considerada por ele uma armadilha, por nos fazer acreditar que é possível transportar uma informação precisa, sem o mínimo de deformação, sobre situações e coisas que não estão presentes (LATOUR, 2004).

A comunicação de duplo-clique trata de coisas que não estão presentes no momento, portanto trata da virtualidade das informações. O manual elaborado por Leide

\footnotetext{
9" Os correspondentes CAIXA AQUI estão espalhados por todo o Brasil e levam os serviços e produtos da empresa aos locais de difícil acesso, onde não existem agências bancárias. Com correspondentes CAIXA AQUI habilitados pode-se preencher propostas de cartão de crédito, conta corrente e cheque especial, ou adquirir empréstimos em consignação e financiamentos imobiliários." (http://www.caixaaqui.imb.br/servicos.html)

${ }^{10}$ Caixa Econômica Federal
} 
baseia-se nos manuais da CEF, que por sua vez tratam de informações sobre os "procedimentos virtuais", que não estão presentes no momento, portanto, necessitam de constante atualização. Sem aviso prévio as versões atualizadas dos procedimentos do programa são lançadas e é responsabilidade de Leide manter-se informada. Isso justifica as rasuras e correções feitas a caneta no manual de Leide.

Leide direcionou-me a outra sala e me entregou uma porção de arquivos, pastas etiquetadas com endereços de imóveis de aluguel, disse para que eu localizasse o CPF dos inquilinos e puxasse as contas atrasadas de água e luz e fixasse junto aos arquivos. Nesse momento um senhor entrou na loja:

"Barbara vem aqui! Acho que isso vai ser mais interessante para você, vou te mostrar como funciona o SIOPI ${ }^{11}$, depois você faz isso"- disse Leide, ao começar o atendimento.

Puxei uma cadeira e me acomodei ao lado de Leide, em frente ao cliente na recepção da loja. O cliente chamava-se Kleber e estava dando entrada ao processo de compra de um imóvel pelo PMCMV havia alguns meses. Kleber tinha conseguido o subsídio integral do governo e já estava com o "dossiê", composto por todos os documentos exigidos pela Caixa para o financiamento habitacional pronto para ser encaminhado à agência, no entanto, um dia antes da imobiliária enviar o dossiê (até então, físico) para a agência, a Caixa mudou as regras do programa e todos os dossiês passaram a ser enviados digitalmente, via SIOPI.

Em consequência da desavisada mudança, Leide e Kleber precisaram reestruturar o dossiê para enviar. Kleber precisou levar até a loja os documentos originais que utilizou na montagem do dossiê físico para que fossem digitalizados e uma nova pasta, dessa vez digital, fosse montada. Aquela ida específica à imobiliária aconteceu para levar a conta de luz do mês de março que havia ficado para trás e era a que ele havia apresentado como comprovante de endereço. Peirano chama atenção em seu trabalho com os documentos de identidade para nossa tendência em acreditar que os documentos possuem características imutáveis, porém o que ocorre é que os documentos sofrem mudanças, são dinâmicos (PEIRANO, 2009) ou como no caso da documentação exigida pela Caixa, possui validade.

\footnotetext{
${ }^{11}$ Sistema de operações imobiliárias
} 
Antes da mudança, os dossiês eram enviados em uma pasta física até a agência bancária e lá eram jogados em um malote com mui tos outros e a própria agência fazia a análise dos documentos. O dossiê digital unificava o sistema de todas as agências Caixa do país. Doravante, não necessariamente uma agência de Planaltina ou do Distrito Federal analisaria o pedido, o que segundo Leide geraria problemas em relação à interpretação dos dados e documentos, de coisas complexas à prosacia leitura dos endereços.

Começamos a trabalhar no processo de Kleber, digitalizando aquilo que faltava e conferindo o que já estava na pasta. Um dos documentos fornecidos pelo cliente, a certidão de nascimento de sua filha, uma de suas dependentes, estava "cortada" no selo de autenticação do cartório, o que faria com que a Caixa rejeitasse o documento, ainda que tal certidão houvesse sido aceita no dossiê de forma física.

Kleber não possuía uma relação com sua ex-esposa e filha. Elas viviam no interior do Piauí, em uma cidade chamada Bom Jesus. Leide pediu para que eu procurasse o telefone do cartório da cidade e ligasse pedindo que eles emitissem uma nova certidão e enviassem por Sedex. Os telefones que encontrei não funcionaram. Encontramos um cartório na internet que realizava o serviço, mas pelo valor de $\mathrm{R} \$$ 300,00 e em um prazo de 30 dias, o que faria com que o processo de Kleber perdesse a validade $^{12}$.

A solução encontrada por Leide era pedir a algum conhecido de Kleber que morasse em Bom Jesus que fosse até o cartório, solicitasse uma nova certidão e enviasse para a imobiliária. Kleber estava adquirindo seu primeiro imóvel, uma casa para ele a atual esposa e os filhos de seu segundo casamento. Leide entendia a dificuldade de seu cliente para produzir aquele documento e o "instruía" a achar uma saída. Os conhecido de Kleber, no entanto, não se dispuseram a ajudá-lo. Ele decidiu então viajar até sua cidade de origem, em busca do documento, deixando a finalização do processo para semana seguinte. Em menos de 3 dias ele foi e voltou do Piauí, trazendo consigo a

\footnotetext{
${ }^{12}$ É estabelecido pela Caixa Econômica Federal que os processos de financiamento têm validade de seis meses, desde a data de aprovação pelo sistema. Caso o processo expire é necessário realizar todos os procedimentos novamente. No caso de Kleber o problema estava na data dos comprovantes apresentados, os comprovantes de renda e de endereço devem ser dos últimos noventa dias, o processo pode ficar no forno por seis meses, mas os comprovantes necessitam ser dos últimos noventa dias, por isso a conta de luz era de março e ambos estavam correndo para entregar o dossiê à Caixa antes que os comprovantes perdessem a validade.
} 
certidão da filha com a qual não se relacionava, mas que desejava mencionar no pedido de financiamento, a fim de garantir o subsídio.

O trabalho de Leide como corretora também consiste, muitas vezes, em fazer mediação entre os clientes, a Caixa Econômica Federal e os construtores e construtoras ${ }^{13}$. Traduzindo os códigos entre essas instâncias, procurando que, ao final, todos se beneficiem da relação. Os clientes que chegam à imobiliária, pelo que pude observar em minha estadia, têm origem muito humilde, de poucas letras. Este fato me foi confirmado por Leide em nossas conversas. Ela se sente responsável em fazer com que os clientes saiam satisfeitos e cientes de todo o processo de financiamento.

Enquanto estive trabalhando na imobiliária apareceram alguns casos de clientes que tinham dado entrada em habitações com outros corretores e imobiliárias pelo PMCMV. Desses, alguns tinham sido ludibriados com taxas ${ }^{14}$ e outros ficaram insatisfeitos com a demora em seus processos. Certa vez questionei Leide a respeito dessas situações. Ela disse que não achava esse comportamento ho nesto e que os corretores faziam isso para prender os clientes ao processo de compra.

Leide faz questão de explicar para seus clientes cada etapa do financiamento: através das simulações, calcula os riscos do financiamento, os riscos das prestações e mostra-lhes as habitações sem forçá-los a adquirir o imóvel. Faz tudo isso pro bono, pois só recebe sua parcela após a finalização do processo e venda dos imóveis, o que nem sempre ocorre (por insolvência do cliente, por dificuldades com os trâmites e documentos etc.). Seu trabalho de instruir não implica a aquisição do imóvel e, por tal função pedagógica, Leide não cobra taxas.

Nesse mesmo dia outra cliente, Denise, procurou a imobiliária de Leide para dar entrada no financiamento habitacional pelo programa. Denise chegou com problemas diferentes daqueles de Kleber. Em certa medida, diametralmente opostos. Denise também era casada. Embora ela e o esposo já possuíssem um imóvel, Denise queria um exclusivo dela, para que ela e sua filha não ficassem desamparadas na falta do marido, que, como Kleber, possuía filhos de um primeiro casamento.

\footnotetext{
${ }^{13}$ Construtores e construtoras, porque os imóveis podem ser construídos e financiados tanto por pessoas físicas como por pessoas jurídicas

${ }^{14}$ Alguns corretores costumam cobrar valores sobre os serviços que deveriam ser gratuitos, como por exemplo, a simulação.
} 
Denise entregou a documentação à Leide para montarmos o dossiê digital. Enquanto Leide analisava os documentos eu abri uma pasta na área de trabalho do computador com o nome de Denise em caixa alta. Ao conferir a identidade de Denise e sua certidão de casamento, Leide constatou que o sobrenome da identidade estava diferente da certidão de casamento e informou Denise que a Caixa não aceitaria a documentação daquela forma e orientou que antes de darem entrada ao processo habitacional a identidade fosse atualizada com o sobrenome de casada. Leide orientou Denize que fosse até o Na Hora ${ }^{15}$ de Sobradinho- DF para fazer a alteração em sua identidade.

As inconformidades, como são chamadas as recusas da caixa, são enviadas alguns dias após a postagem dos dossiês no SIOPI, geralmente por e-mail. Parte do trabalho de Leide consistia em diminuir ao máximo as chances de inconformidades serem detectadas. Se não há inconformidade nas documentações do cliente, do imóvel e dos vendedores, o processo é aprovado e o cliente estará apto a assinar o contrato de financiamento habitacional.

As histórias de Kleber e de Denise nos mostram dentre as exigências para o financiamento habitacional está necessidade de se comprovar pessoa digna de tal benefício. Para usufruir do subsídio do programa Kleber e Denise necessitam comprovar quem são e sua história financeira por meio das documentações exigidas pela Caixa.

\section{A Simulação}

O primeiro passo a ser dado quando se tem interesse em financiar uma casa através do Programa Minha Casa Minha Vida é realizar uma simulação de renda, para fazer uma simulação são necessárias as seguintes informações; número de CPF, data de nascimento, valor da renda, valor do imóvel que pretende adquirir, a cidade em que se localiza o imóvel, se interessa em utilizar FGTS como entrada, se possui dependentes (filhos ou cônjuge) e se já foi beneficiado com o subsídio FGTS/união.

\footnotetext{
${ }^{15}$ "O Na Hora foi instituído pelo Decreto no 22.125, de 11 de maio de 2001, o Na Hora reúne em um único local, representações de órgãos públicos federais e distritais, de forma articulada, para a prestação de serviços públicos aos cidadãos. O Na Hora tem como finalidade facilitar o acesso do cidadão aos serviços públicos, simplificar as obrigações de natureza burocrática, assim como ampliar os canais de comunicação entre o Estado e o Cidadão".

http://www.nahora.df.go v.br/sobre-o-na-hora/conceito.html acesso em 05/12/2017
} 
O simulador habitacional é uma ferramenta, que está presente no endereço eletrônico da CEF, em que pode-se simular diversos tipos de financiamento. Através da simulação é possível antecipar as condições de financiamento dos imóveis, a quantidade de parcelas, valores de prestações, juros etc. A simulação ajuda Leide a "montar" um financiamento que caiba dentro das condições financeiras de seus clientes ${ }^{16}$.

Para simular é necessário ter em mão os comprovantes de renda e documentos pessoais $^{17}$, a simulação pode ser feita pela internet ou nas imobiliárias. É preciso apena s preencher um formulário com os dados que o próprio sistema gera as opções de financiamento disponíveis de acordo com os dados fornecidos. O fator renda influencia diretamente no tipo de financiamento e no preço imóvel, pois o valor do imóvel é inversamente proporcional ao subsídio fornecido pelo governo e a cota máxima de financiamento.

A política pública PMCMV é considerada por muitos especialistas como a maior iniciativa do governo para promover habitação no Brasil atual. Alguns, no entanto, como urbanistas e ativistas da reforma urbana, consideram que tal política pública é marcada por um viés extremamente mercadológico. Por meio do programa, ao mesmo tempo em que se promove o acesso à a moradia (através do consumo), igualmente, por conta do endividamento que a financeirização implica, alija-se milhares de pessoas de alguns direitos básicos (Rolnik, 2015).

Os empreendimentos são construídos em locais que podem até serem distantes dos centros, mas são imóveis que, em teoria, possuem estrutura, ou, no jargão local, o que se chama de "padrão caixa", estando em áreas com saneamento básico. A grande questão é que a população precisa pagar para ter acesso a esses bens, um pagamento em longas prestações e com juros. O que é avaliado pelos laudos de imóveis da CEF é o mínimo, pois além da estrutura física da casa, do saneamento, asfalto e iluminação outras categorias entram em jogo, mobilidade e segurança são algumas delas. Esse quadro complexo implica contradições diversas, pois enquanto o programa promove acesso a alguns bens, que seriam bens de direito da população, ele nega outros, ao fazer vistas grossas para sua inexistência.

\footnotetext{
${ }^{16}$ Ver trecho de entrevista no início do capítulo.

${ }^{17}$ Identidade e CPF
} 
A simulação era o processo que os corretores estavam realizando no dia que os encontrei na rodoviária do plano. Eles recolhiam os dados, levavam até a imobiliária em que trabalhavam, faziam as simulações e entravam em contato com os clientes para informar das condições do financiamento. Trata-se de um processo bem simples, que não exige nenhum tipo de comprovação e que pode ser realizado pelo próprio cliente. Sendo assim, outra pergunta surge: qual o papel do corretor nessa transação aparentemente tão sem percalços e de relativamente fácil entendimento?

Após a simulação o próximo passo a ser dado em direção ao sonho é a produção por meio de documentos as informações exigidas pela Caixa. Além da documentação pessoal do cliente, no caso do MCMV, exige-se a documentação de seus dependentes e cônjuge; comprovante de endereço; documentação do imóvel que será financiado e dos vendedores do imóvel. Aqui costuma entrar a determinante figura do corretor de imóveis. 
Documentação básica para

solicitação de Crédito

COMPRADOR(ES) - PF (Pessoa Física)

-. Documento oficial de identificação

*. Comprovante de renda atualizado, emitido no máximo há 2 meses

\section{USO DO FGTS}

- Última declaração do Imposto de Renda e recibo de entrega à Receita Federal

.. Carterra de Trabalho ou Extrato de FGTS

IMOVEL

-. Certıdão Atualizada de Inteiro teor da Matrícula

VENDEDOR(ES) - PF (Pessoa Fisica)

-. Documento oficial de identificação

-. Comprovante de estado civil

\section{VENDEDOR(ES) - PJ (Pessoa Jurídica)}

-. Representante Legal: Documento oficial de identificação

.. Empresa Ltda ou Firma Individual:

- Documento de constituição e alteraçōes devidamente registradas e

Certidão Simplificada da Junta Comercial

-. Sociedade Anónima (S/A):

- Estatuto Social e Ata de Eleição da última Diretoria publicada no

Diário Oficial

\section{OBSERVAÇÕES}

- A CAIXA oferece modalidades de financiamentos com condiçōes e vantagens especiais.

- Realize uma simulação em uww.caixa.gov.br e conheça nossos planos.

.. É facultado à CAIXA solicitar documentos adicionais 
O Clássico de Marcel Mauss sobre a construção noção de pessoa como uma categoria do espírito humano inspirou minhas reflexões sobre a construção da "pessoa virtual" na simulação dos processos habitacionais. A reflexão de Mauss apresenta nossos antepassados constituindo-se enquanto pessoas sociais através do uso de máscaras e nomes de seus antecessores, por meio dessas máscaras, nossos antepassados personificavam seus entes, divindades e se constituíam enquanto seres, podendo assumir a identidade de cada uma dessas máscaras, ou de todas elas, a depender do que sua sociedade exigisse (MAUSS, 1938).

No caso do Programa Minha Casa Minha Vida, Denise e Kleber, fazem o uso dos dossiês como máscaras, cada uma representando um "papel" que eles precisam apresentar. Eles simulam e simular é fazer uma estimativa, como é a simulação realizada antes da aquisição do imóvel, mas é também fingir e colocar-se em um lugar onde não se está, lugar este que está em outro momento, no futuro.

O que acontece no processo de financiamento é a construção de um "avatar" a partir da comprovação dos requisitos exigidos pelo programa com documentos. Mariza Peirano traz uma discussão interessantíssima sobre os documentos de identidade que pode trazer luz às nossas reflexões. A autora trabalha com a ideia de que os documentos são provas materiais que a testam a veracidade da nossa autoidentificação, nas palavras da autora:

"No mundo moderno, documentos são objetos indispensáveis, sem os quais não conseguimos demonstrar quem somos. Precisamos de provas materiais que atestem a veracidade da nossa autoidentificação, já que por nós próprios esse reconhecimento é inviável" (PEIRANO, 2009, p.63).

A etnografia de Bachtold nos conta sobre a "magia" do pedaço de papel, documento, que se transforma na principal fonte de comprovação dos indivíduos, em sua pesquisa sobre os números e o Cadastro Único a autora demonstra a exigência do Estado em que as pessoas pobres "provem" sua condição:

"Ainda que autodeclarada, como pressupõem as normativas do programa, a renda precisa ser checada, auditada, fiscalizada, para que um olhar externo, supostamente isento, confirme que os pobres são realmente quem dizem ser" (BACHTOLD, 2017, p. 109) 
O mesmo acontece com aqueles que almejam os benefícios concedidos pelo governo no que diz respeito ao PMCMV, na simulação e apresentação dos documentos à CEF os clientes de Leide necessitam "provar" sua condição. Kleber, Denise e Leide buscam na montagem dos dossiês reconhecimento para as informações fornecidas durante a simulação, por isso a precisão e cautela na escolha e apresentação dos documentos.

O trabalho de Paterniani sobre as ocupações em São Paulo nos mostra que a compreensão da política em um sentido amplo ou "ação política" é composta por elementos de resistência, de reivindicação e de prefiguração (PATERNIANI, 2013). Não diferente da "ação política" empreendida pelas ocupações e movimentos sociais, a "ação política" empregada por Leide e seus clientes, também fazem uso de elementos de resistência, na montagem, preparação e espera dos processos a serem encaminhados à Caixa, reivindicação do benefício e prefiguração, antecipação dos resultados. O processo segue para Caixa Econômica Federal completo, constando inclusive a casa que será adquirida pelo beneficiário do programa após aprovação.
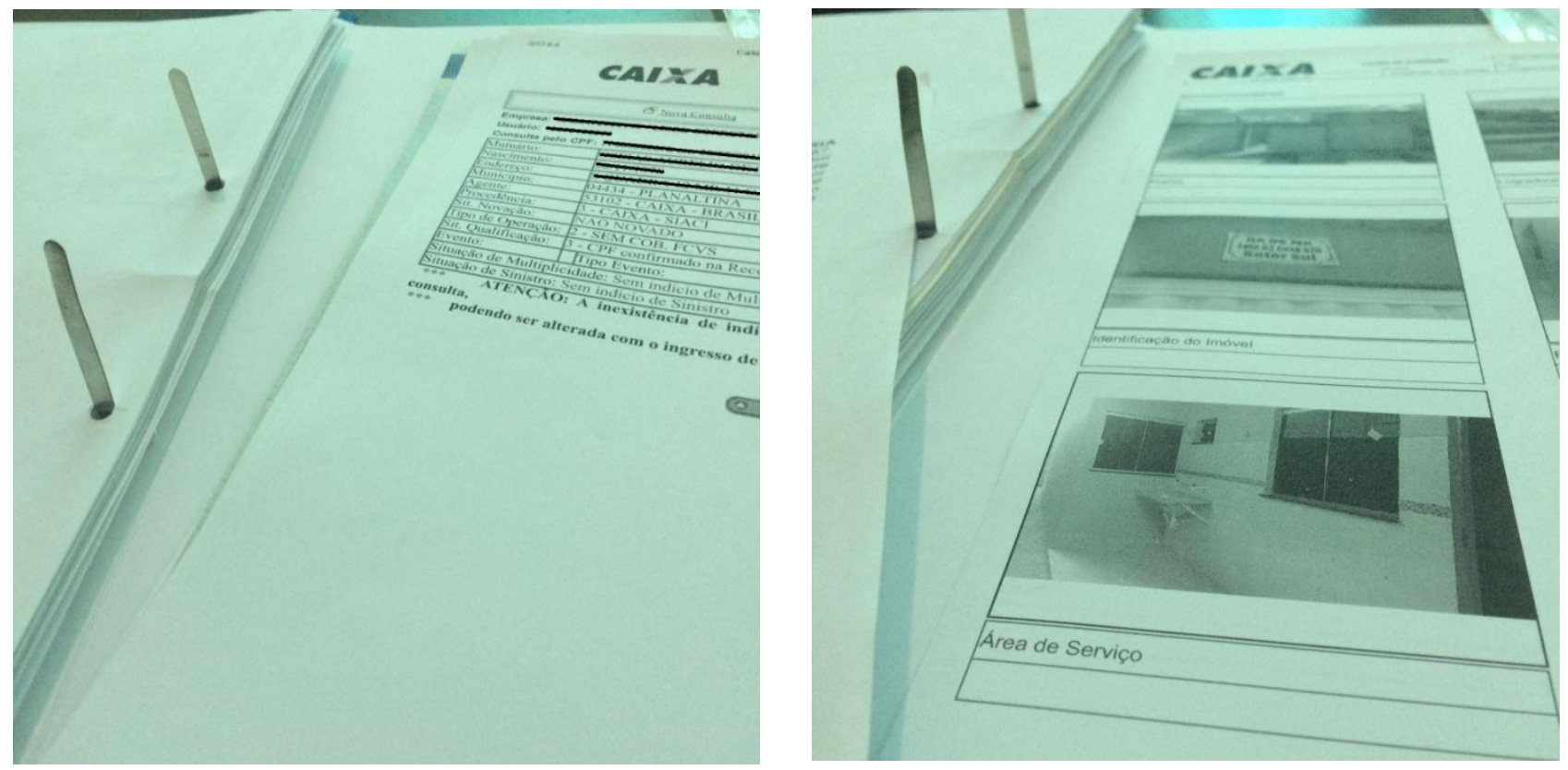

Dossiê físico composto por todas as informações do processo de financiamento imobiliário, desde a documentação dos beneficiários até a dos vendedores e dos imóveis. 
Os clientes

Leide: -Ele já solicitou os laudos das casas da Leste ${ }^{18}$ ? - Perguntou Leide ao pedreiro que estava trabalhando em uma das construções, se referindo ao engenheiro da obra.

Trabalhador: - Ainda não, Dona Leide, ainda falta acabamento- respondeu atencioso.

Leide: -É bom ele pedir logo... Os laudos andam vindo muito baixos. A Casa do Otávio mesmo vamos pedir uma reavaliação, pedimos $R \$ 160.000$, porque a gente sempre pede o máximo, mas o engenheiro avaliou como $R \$ 120.000$. E a casa lá é muito boa, com blindexe e suíte... E também com as mudanças que estão pra acontecer a gente não sabe, é bom pedir, fala com ele que se ele quiser eu posso solicitar, só ele me entregar a documentação do imóvel.

Trabalhador: -Eu dou o recado.

Leide: -Nossa e essa aqui está ficando grande! Olha aqui, Barbara! Tem quintal no fundo?- Disse Leide me convidando a entrar na casa.

Trabalhador: -Essa aqui tem, as outras duas não.

Leide tinha tirado à tarde para mostrar alguns imóveis a uma cliente e aproveitou para fazer vistoria em outros. Convidou-me para acompanhá-la. Na volta paramos em uma construção, eram três casas em um mesmo lote. Os trabalhadores estavam assentando o piso e fazendo as instalações elétricas. O diálogo acima retrata o momento em que Leide parou para conversar com os trabalhadores nessa construção, enquanto eu explorava os cômodos da casa, atenta a conversa.

Mostrar imóveis e fazer vistorias são atividades cotidianas da imobiliária. As vistorias geralmente acontecem nos imóveis de aluguel, quando os inquilinos estão entrando ou saindo. Leide desloca-se até os imóveis para checar se está tudo certo com as instalações e pinturas. Também é comum os clientes chegarem na imobiliária e pedirem para visitar os imóveis, tanto para aluguel quanto venda, o processo usual é entregar a chave a essas pessoas, mas Leide muitas vezes oferece para mostrar as casas pessoalmente, principalmente quando o cliente está a pé, ela o leva até os imóveis.

${ }^{18}$ Leide se refere aqui ao setor Leste de Planaltina-GO 
Essa construção era composta por três casas em um mesmo lote, estavam todas inacabadas. As casas estavam no reboco, mas já contavam com uma placa em que se lia "vendo", logo na entrada, não era a placa da imobiliária de Leide. As casas seguiam o "padrão caixa" de cozinha americana, sala, banheiro, dois quartos, um com suíte e uma delas possuía quintal, todo cimentado. Leide e o pedreiro conversavam, pareciam antigos amigos, o interesse dela era falar com o responsável pela obra, que não se encontrava no momento.

A clientela de Leide, além dos compradores, inclui também os "vendedores", que podem ser construtoras que utilizam a imobiliária para promover seus empreendimentos ou pessoas físicas, que por alguma razão decidem vender seus imóveis ou que constroem habitações para serem exclusivamente vendidas, nesse caso através do financiamento. Até o período em que estive com Leide a CEF aceitava pessoas físicas como vendedoras, mas a regra estava prestes a mudar, por isso Leide cita as "mudanças que estão pra acontecer", mudanças referentes aos vendedores, que passariam a serem aceitos apenas como pessoas jurídicas, e também em relação aos laudos que estavam mais criteriosos.

A Caixa exige dos imóveis que financia um laudo emitido por engenheiros credenciados pelo próprio banco, atestando o estado das obras. A solicitação também é realizada pelo SIOPI que exige ainda o envio de toda documentação do imóvel, além dos documentos pessoais dos responsáveis pela obra e vendedores. Após a avaliação do dossiê do imóvel, a Caixa agenda a visita do engenheiro, que pode ser alocado de qualquer cidade de Goiás ou Distrito Federal para fazer a vistoria. O engenheiro responsável pela vistoria preenche uma ficha com os dados do imóvel de acordo com sua adequação às exigências da Caixa e, no final, determina seu preço. 


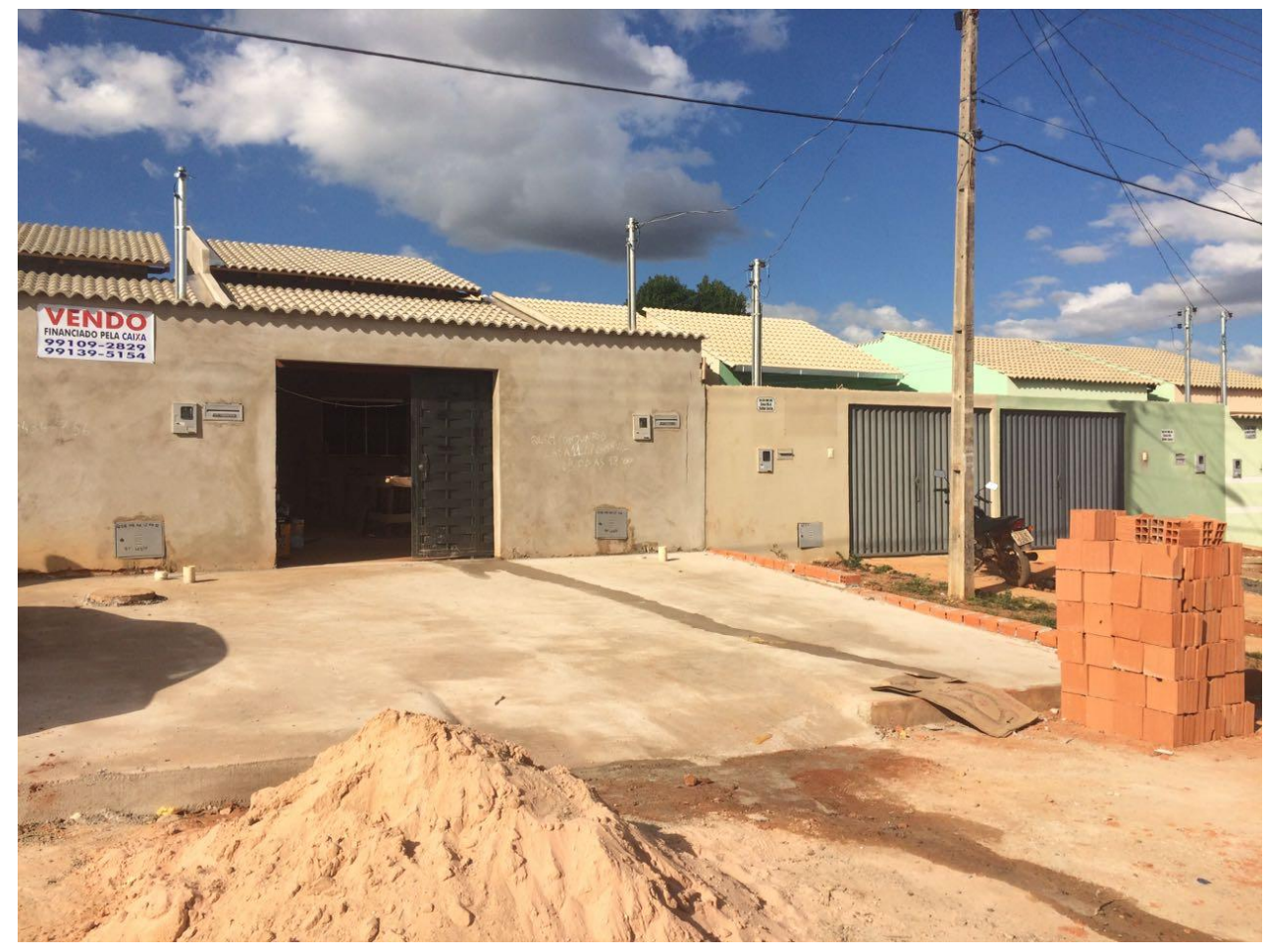

Construção

A rua em que estávamos não era de um condomínio fechado, mas lembrava de um, pois grande parte das casas foram construídas de forma similar, todas aos moldes exigidos pela Caixa. Havia um segmento de lotes com casas trigêmeas e alguns lotes vazios intercalando os pequenos conjuntos, forma como são chamadas as construções com o seguinte formato. Em outra rua as construções intercalam pequenos prédios individuais, também condomínios de habitações financiadas pelo PMCMV.

Patriota De Moura (2012) em sua etnografia sobre os condomínios nos convida a conhecer a proliferação dos condomínios em Goiânia e Brasília como uma nova forma de expansão urbana. Os condomínios, antes reconhecidos e conceituados como habitações das camadas médias, que buscavamisolar-se por meio dos muros e grades de segurança, passaram a caracterizar o perfil das camadas populares, que no Distrito Federal passaram a adquirir loteamentos irregulares, os chamados "condomínios de baixa renda", e através da autoconstrução habitar esses espaços.

O PMCMV por sua vez, em alguns de seus empreendimentos, reproduz a mesma lógica de isolamento e "segurança" dos condomínios apresentados pela autora. Em muitas construções é comum um muro delimitando o espaço do condomínio, a guarita 
de segurança, as "casinhas padrão" e área de lazer, com churrasqueira e parquinho para as crianças. Em Planaltina era comum ver propaganda dessas iniciativas, voltadas para um público com maior renda, mesmo na imobiliária de Leide havia panfletos, banners e diversas propagandas desses condomínios.

No entanto, em grande parte da cidade, o que se observa são aglomerados de "casinhas padrão", que não se configuram como condomínios, mas são idênticas e muitas vezes construídas pelas mesmas pessoas ou grupo.

O trabalho de Leide consiste em mediar seus clientes e a agência bancária de financiamento, diminuindo ao máximo os riscos, que vão da venda à compra. Seu papel é identificar os códigos necessários para a aceitação dos processos de compra e venda por meio do financiamento e reproduzi-los, de forma transparente e didática, no processo de cada novo cliente que chega à loja, sendo ele construtor ou comprador.

A linguagem dos manuais da CEF é por vezes ambígua e faz-se entender por aqueles que dominam os códigos das transações bancárias e imobiliárias. Sabendo disso os clientes de Leide a procuram para realizar consultas relativas à negociações e pedir conselhos, tendo em mente que ela fará o possível, dentro das limitações dos sistema, para ajudá-los.

Latour (2004) ainda em suas ponderações sobre a existência de formas de discurso e a linguagem de duplo-clique nos conta que algumas formas de discurso são capazes de transmitir pessoas e não informação (LATOUR, 2004). Pergunto-me se a forma de transmissão de informação a qual Leide propõe-se a realizar, traduzindo os códigos imobiliários de "duplo-clique", não seja em parte, o tipo de comunicação capaz de transmitir pessoas, a qual o autor se refere. Leide transforma por meio dos códigos seus clientes em pessoas para o Estado, dentro da burocracia da CEF, Leide as torna aptas a receber o benefício do PMCMV. 

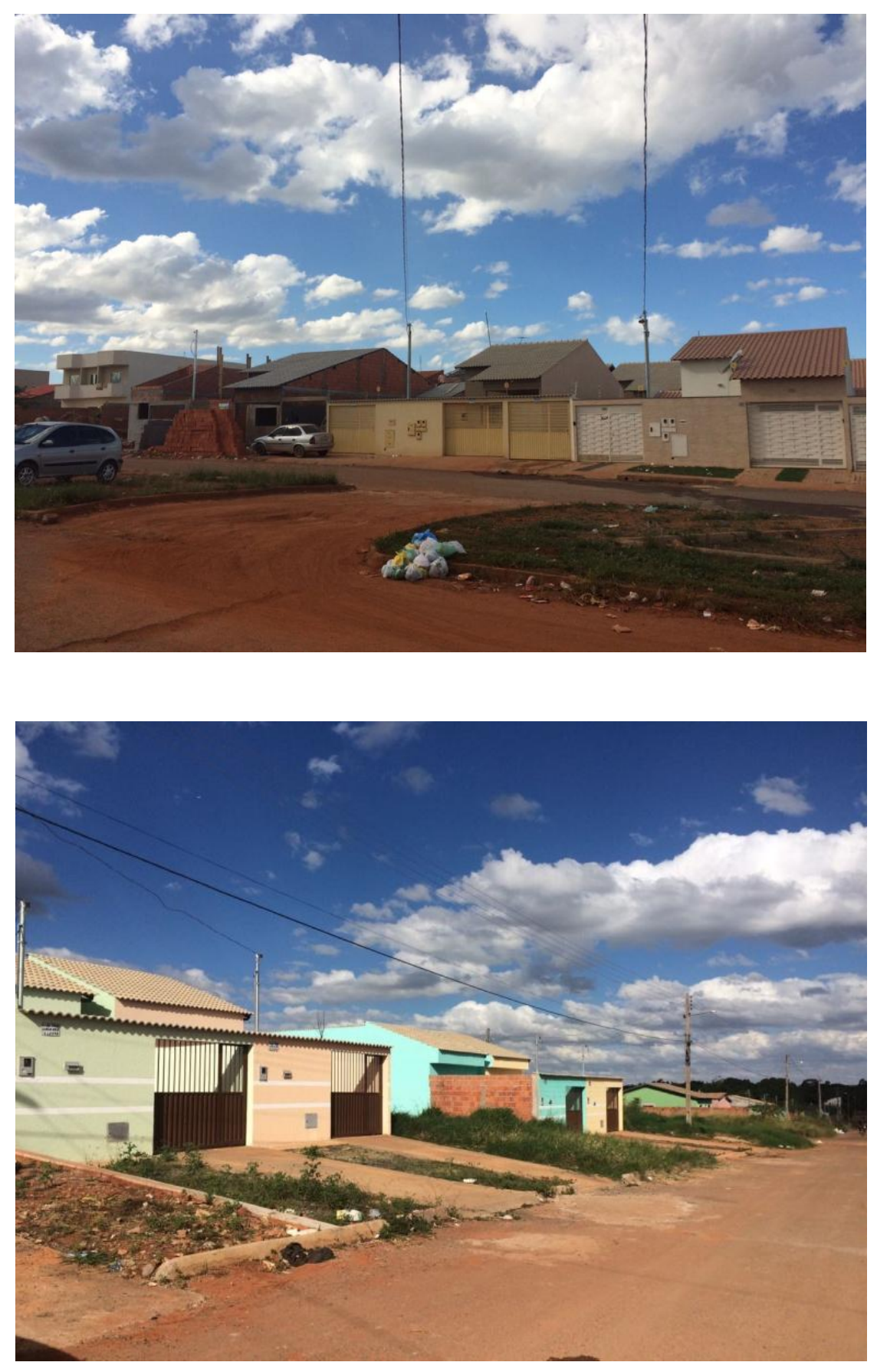

Ruas de Planal tina- GO 


\section{PARTE II - De usuária à Vendedora}

Em uma manhã de segunda, duas semanas depois que eu havia começado a acompanhar Leide, cheguei à imobiliária mais cedo que o usual. A loja ainda não estava aberta, o comércio em volta começava a acordar. Sentei-me na parada de ônibus que ficava quase em frente à imobiliária e aguardei. Do outro lado da rua avistei uma jovem mulher, também esperando, trocamos olhares, mas não nos falamos.

Leandro, funcionário de Leide, chegou e subiu as portas da imobiliária. Começamos a fazer nossas atividades habituais, entrei, fui fazer café e ele a limpeza da loja. Leide chegou acompanhada da jovem mulher e nos apresentou:

-Gente, essa é a Eliene que vai trabalhar com vocês. Eliene, esse é o Leandro seu colega de trabalho - disse Leide se virando para Leandro- e essa é a Barbara estudante da UnB que está tendo uma experiência aqui comigo na imobiliária, estou ajudando na escrita da monografia dela- disse Leide com um sorriso para mim- Vem cá que eu vou te mostrar como funciona a loja?!

Eliene passou por nós com um sorriso tímido, retribui o sorriso e continuei meus afazeres.

Leide aceitou-me como sua ajudante em um período em que a imobiliária estava desfalcada de uma funcionária. Eu entrei para ajudá-la em atividades corriqueiras e de pouca complexidade até que ela encontrasse outra pessoa para ocupar a função. Meu trabalho se resumiu a organizar arquivos, digitar documentos, fazer cópias na máquina Xerox, atender telefonemas e fazer companhia a Leide em algumas vistorias.

Poucos dias após meu trabalho de pesquisa ter-se iniciado, Leide selecionou a nova funcionária, Eliene que, de fato, trabalharia na imobiliária. Certa quarta-feira, Leide me convidou para acompanhá-la em uma de suas visitas à Caixa Econômica Federal, agência de Planaltina DF, a qual Leide era correspondente. Enquanto conduzia, Leide acompanhava uma canção gospel com voz delicada e afinada.

Leide confessou-me estar muito feliz com a contratação de Eliene, pois elas eram antigas conhecidas da igreja. Além disso, Eliene, que trabalhava como manicure aos sábados, fazia as unhas de Leide. Para Leide, encontrar bons funcionários é difícil: a maioria começa bem, mas depois deixam de cumprir com suas responsabilidades. $\mathrm{Na}$ 
escolha da nova funcionária, Leide utilizou de um método que levava em conta tal adversidade. Ela tinha três nomes em mente, nomes de pessoas conhecidas, que ela acreditava serem boas para o trabalho. Para que um deles emergisse como o definitivo, mais acertado, empregou muitas orações. Além disso, Leide escreveu os três nomes em um papel e o entregou ao pastor de sua igreja, pedindo-lhe orações e que a informasse se sentisse alguma coisa por um dos nomes.

Um dia, após voltar para casa, cansada, Leide recebeu uma mensagem pelo whatsapp de Eliene. Era um vídeo de um hino, que segundo ela dizia tudo o que ela precisava escutar após um dia de trabalho. Eliene foi a escolhida.

Eliene trabalhava como doméstica em uma residência localizada na Asa Norte. Ela deslocava-se de Planaltina ao Plano Piloto de segunda a sexta, aos sábados pela manhã fazia curso técnico em enfermagem e pela tarde trabalhava de manicure. Sabia também fazer cabelos, sobrancelhas e depilação. Para ela, a mudança de emprego e o contrato com Leide facilitaria sua rotina. Ela não precisaria mais viajar a distância de 60 $\mathrm{km}$ até o Plano para trabalhar, sobrando-lhe mais tempo para dedicar à filha e seus estudos.

Os pais de Eliene se mudaram do Pará para Planaltina-GO quando ela ainda era criança. Apesar da infância humilde, sem muitos recursos financeiros, Eliene nunca deixou de estudar e confessou-me que um de seus sonhos é chegar ao nível superior, cursar pedagogia e ser professora. Estava se profissionalizando em um curso técnico, porque depois da chegada da filha, Ana Clara, suas prioridades tornaram-se outras. Seu objetivo é conquistar aquilo que não teve na infância para Ana Clara. Inclusive a estabilidade de morar em uma casa própria, e não ter que ficar mudando de aluguel em aluguel.

O nascimento de Ana Clara provocou grandes mudanças na vida de Eliene, ela me dizia várias vezes, que antes todos os seus esforços eram para usufruto próprio, agora tudo era para Ana Clara. Antes de tornar-se mãe, Eliene morava sozinha, mas quando engravidou e nas palavras dela "viu que a pessoa com quem tinha se envolvido não ia ajudar em nada e não valia uma nota de três reais" voltou a morar com sua mãe, porque precisava de ajuda para cuidar da criança. Nessa época seu pai havia falecido.

Em uma de nossas conversas, que teve como ponto de partida um fato que saiu no noticiário, a notícia era que uma mãe havia dado à luz e abandonado o bebê em uma caçamba de lixo, Eliene comentou que entendia o sentimento dessa mãe e não julgava a 
atitude dela como errada, pois tinha passado pela experiência de estar grávida sem o apoio de seu companheiro e o sentimento é desesperador. $\mathrm{Na}$ época em que descobriu a gravidez, contou que pensou em enviar a criança para adoção, mas sua mãe ao escutar tal ideia a proibiu de fazer isso, justificando que o bebê que Eliene estava carregando não era cachorro para sair dando para os outros, e prometeu que enquanto estivesse viva ajudaria nos cuidados com a neta.

Hoje Eliene e Ana Clara são inseparáveis, prova disso são os esforços de Eliene para dar a filha o que nunca teve. Não só uma casa própria, mas também um lar, um lugar só delas, sem ameaças de despejo, em que possam criar suas memórias e laços afetivos. Eliene, assim como muitos outros brasileiros, resolveu assumir o risco da dívida de um financiamento para sair do aluguel e adquirir um bem, que está em seu nome, mas não é seu. A casa é das três, Eliene, sua mãe e Ana Clara, no entanto só receberão a escritura do imóvel quando a dívida estiver quitada.

\section{Por trás do balcão}

Em seus primeiros dias de trabalho, Eliene acompanhava Leide de um lado para o outro com um caderno, anotando passo a passo o serviço que lhe era passado, quando não estava com o caderno, gravava vídeos no celular para os momentos em que fosse realizar as tarefas sozinha. No início confessou estar um pouco perdida e tendo dificuldades com novo emprego, pois não estava acostumada a usar computadores. Aos poucos Eliene foi entrando no ritmo e passou a compreender "de dentro" os mecanismos do financiamento, antes conhecidos por ela pela perspectiva da cliente, de quem estava financiando uma habitação.

Outra das responsabilidades de Eliene na imobiliária era cozinhar. Ela preparava o almoço todos os dias e algumas vezes o lanche, na cozinha da imobiliária. Eu por ser de natureza inquieta sempre a ajudava no preparo dos alimentos, lavando algumas coisas e até fazendo atendimentos enquanto ela cozinhava. Leide estava sempre resolvendo assuntos urgentes, dentro e fora da imobiliária.

Em uma manhã, por volta de mais ou menos 10h, Eliene e eu estávamos sozinhas: eu na cozinha lavando a louça, enquanto ela organizava o almoço. Eliene foi até a recepção e passados alguns minutos escuto sua voz. Sai da cozinha em direção à recepção para ver se algum cliente havia chegado e se ela precisava de mim. Eliene 
estava a sós, para minha surpresa, sentada na ponta da cadeira, de avental e com os óculos na ponta do nariz. Perguntei a ela o que estava acontecendo, ela me olhou por cima dos óculos com uma feição indignada e apontando para calculadora disse:

-Estou fazendo o cálculo do meu financiamento, de quanto ainda falta pra eu pagar, vi a Leide fazer essa conta outro dia... Acredita que eu ainda nem comecei a pagar o valor da casa?

-Não entendi Eliene - respondi, ainda sem assimilar do que ela estava falando

-Chega aqui -disse ela, chamando-me para perto de si.-Olha só, o valor da minha casa na época era $R \$ 115.000$, eu dei $R \$ 44.000$ de entrada e financiei $R \$$ 78.000 e pago $R \$ 584,00$ de prestação, se eu multiplicar o valor das prestações por 360, que foi a quantidade de vezes que dividi, e somar com a entrada dá $R \$ 254.240$, mais que o dobro do valor da minha casa... Eu ainda nem comecei a pagar o valor da minha casa, se a gente multiplicar o valor das prestações pela quantidade de parcelas que já foram pagas, eu paguei só $R \$ 14.016 \ldots$ E a gente acha que financia e paga $R \$ 78.000^{19}$

-E o que você acha disso?- perguntei-lhe, curiosa.

-Eu acho que é uma roubada! Mas é uma roubada muito boa, porque quando eu ia ter $R \$ 115.000$ pra pagar à vista, numa casa? Fora que morar na minha casa é outra coisa... É melhor ficar pagando 30 anos e ter um teto do que pagar aluguel e correr o risco de ser despejada. Sem falar no desgaste dos móveis...Tinha um guarda-roupas que sempre que eu passava na loja ficava namorando ele, mas eu não podia comprar, porque quando a gente mora de aluguel a gente tem que ficar mudando, ele ia estragar rapidinho. Quando eu comprei a minha casa eu fui na loja e comprei um guardaroupas ainda mais bonito, enorme, com porta de correr e espelhos - Em seguida complementou seu raciocínio- Barbara, eu acho o Programa Minha Casa Minha Vida muito bom, eu acho que todo mundo que não tem um teto deveria fazer um financiamento. Mas as pessoas acabam tendo medo, como eu já ouvi de algumas. Medo porque é um financiamento longo, porque você vai passar 30 anos da sua vida pagando uma casa. Mas se você não compra ela, você vai passar 30 anos da sua vida pagando uma casa do mesmo jeito, só que quando chegar os 30 anos, a casa não é sua. Então eu acho muito bom e aconselho todo mundo a fazer o seu [financiamento] ${ }^{20}$.

\footnotetext{
${ }^{19}$ Os valores foram arredondados para melhor compreensão

${ }^{20}$ Este diálogo misturou uma conversa que aconteceu e trechos da entrevista que realizei com Eliene.
} 
A fala de Eliene nos mostra, que mesmo do outro lado do balcão, sua compreensão do programa Minha Casa Minha Vida é a mesma que possuía quando adquiriu seu imóvel, para ela por mais que o programa tenha uma lógica de exploração é a única forma que as camadas de renda mais baixa da população possuem de adquirir habitação própria.

\section{"Meus clientes sonham com algo muito melhor"}

A pesquisa de Erik Bähre (2007) traz uma reflexão que nos ajuda a compreender aquilo que Eliene chama de "roubada mui to boa". O trabalho do autor nos conta sobre a venda de seguros na Africa do Sul, em Cape Town. Em sua pesquisa Bähre trabalha com a ideia de "a crueldade da solidariedade", os termos podem parecer antagônicos, mas o que querem dizer é que políticas que tem como objetivo "sanar desigualdades", regular e redistribuir renda ou terra para citar novamente Rolnik (2015) e que se vendem como redutoras de desigualdade, continuam reproduzindo a lógica do sistema, promovendo desigualdades e exclusões.

Eliene nos fala que "todo mundo que não tem um teto deveria fazer um financiamento", mas quem são as pessoas que não tem um teto? E por que elas não fazem um financiamento? O PMCMV pode ser compreendido como uma política de solidariedade, que tenta promover a redução da desigualdade e alocação de terras por meio do incentivo governamental, o fato contraditório é a conta de Eliene não fechar e os usuários acabarem pagando mais que o dobro dos imóveis.

A reflexão de Bähre nos conta o quanto essa lógica de redução de desigualdades é irônica ao prometer o acesso a bens, mas também promover tensões que agravam as desigualdades. Lembro-me que na primeira conversa que tive com Leide ela contou das "mulheres sofridas" que a visitavam em sua sala. Muitas iam até a imobiliária para desabafar e pedir ajuda, pois não conseguiam arcar com as despesas do financiamento de seus imóveis.

Uma dessas histórias me chamou atenção, a história de uma senhora aposentada que procurou Leide para financiar uma casa que abrigasse toda sua família, que era composta por ela e as famílias de seus filhos. Após alguns meses de financiamento a senhora voltou a procurar Leide, pois não estava conseguindo arcar com as despesas da casa, o que segundo Leide devia-se ao fato dos "filhos escorarem nela com suas 
famílias". Leide vendeu a casa e com o dinheiro convenceu a senhora a comprar um lote em um local afastado, antes que seus filhos interferissem e acabassem por gastar o dinheiro com outras coisas, "hoje ela está lá morando em um barraquinho", disse-me Leide.

As reflexões sobre a burocracia na Índia de Akhil Gupta trouxeram grande luz aos questionamentos colocados sobre o Programa Minha Casa Minha Vida. Apesar de contextos um pouco diferentes, Brasil e Índia são alvo de políticas que visam promover o desenvolvimento e tirar as pessoas da pobreza. No entanto a elaboração dessas "políticas inclusivas" se dá de maneira paradoxal e no fundo não conseguem atingir sua verdadeira "população alvo", exemplo deste fato é que mesmo após anos a implantação do PMCMV o déficit habitacional do Brasil continua crescendo.

Gupta nos fala de uma extrema pobreza endêmica que deveria ser teorizada como uma forma de assassinato, um tipo de violência contra as pessoas pobres. As políticas desenvolvimentistas promovem acesso a determinados bens a uma camada da população, aquela que consegue "tornar-se pessoa" sabendo fazer uso da burocracia com auxílio de Leide. A outra acaba por sofrer "inconformidade", exclusão, a morte do processo. O autor denominou esse tipo de violência como "violência estrutural"; "A razão pela qual tal violência é considerada estrutural é a dificuldade em identificar um único ator que a comete. Ao invés disso a violência é impessoal, construída na estrutura de poder" (GUPTA, 2012, p.20, tradução minha). Essa violência é manifestada na privação do direito a moradia, por meio dos manuais o Estado e a CEF decidem a que m é permitido o subsídio e o financiamento habitacional.

Os empreendimentos financiados pelo PMCMV são a oportunidade oferecida pelo governo federal (i) a quem não possui habitação própria de morar, que o faça adquirindo uma dívida e (ii) a proprietários que encontram liquidez imediata e baixos riscos ao investirem no mercado imobiliário com a garantia de subsídios governamentais. Para nossas interlocutoras, por meio do PMCMV foi encontrada uma maneira de pagar em longas prestações por uma moradia cercada de condições - asfalto, iluminação e saneamento básico - inexistentes em locais onde poderiam morar de aluguel ou nos chamados condomínios de baixa renda, localizados em zonas clandestinas, chamadas comumente de invasão (BORGES, 2004). 
Uma Casa financiada através do Programa Minha Casa Minha vida não é a realização de um sonho, mas de uma necessidade. A própria Leide nos conta que "meus clientes sonham com algo muito melhor, mas a casa do Programa Minha Casa Minha Vida é o que eles conseguem comprar". Apesar da exploração feita pelo sistema de financiamento os clientes de Leide veem no programa a única saída para adquirir uma moradia própria com o míni mo de estrutura. 


\section{Considerações finais}

Passados alguns meses da minha estadia com Leide resolvi visitá-las em uma tarde de Setembro. Já fazia quase um ano do meu encontro com os corretores e início da pesquisa sobre o Programa Minha Casa Minha Vida. Conversávamos animadamente envolta da mesa da cozinha, após apreciar um delicioso almoço preparado por Eliene. Em nossos pés rolava uma cachorrinha sapeca, Sophia, filha mais nova de Leide, na época com três meses de idade e uma semana de adoção.

Leide brincava e ria da bichinha, que se esfregava com todo amor no colo da mãe. Leide passou a manhã daquele dia fora da imobiliária em uma reunião com novos construtores que chegavam à cidade, arquitetos e engenheiros que vinham de Brasília com interesse em montar um condomínio residencial em Planaltina-Go. Na intenção de compreender o mercado convocaram uma reunião com alguns corretores da cidade, a qual Leide havia participado pela manhã.

Eliene, ansiosa pelas novidades, perguntou: - Como foi na reunião, Leide?

Leide: -Ah?! Eu fui sincera. Acho que eles não gostaram não, me olharam com a cara feia, principalmente os corretores aqui da cidade, mas pra quê ficar iludindo o povo?

$\mathrm{Eu}:-O$ que eles queriam com você?

Leide: -É porque assim, Barbara, uma construtora de Brasília quer construir aqui uns condomínios, apartamentos, mas o problema é que eles querem vender na planta. E eu já avisei logo que aqui na cidade não tem mercado pra isso.

Eliene: -Aqui o pessoal não tem dinheiro pra pagar conta de luz!

Leide: -Eu falei que aqui a pessoa quando compra uma casa, ela compra pra morar. Ninguém tem condições de comprar uma casa e ficar pagando sem morar, esperar o apartamento ficar pronto. E eles não entendem isso.

Eliene: -A pessoa já compra a casa pra sair do aluguel, não tem condições de ficar esperando a casa sair. Enquanto a casa não sai ela vai morar onde? Se a maioria deixa de pagar o aluguel pra pagar a prestação e morar no imóvel? 
Leide: - Eu avisei. Eles querem o dinheiro pra ir custeando a obra, mas aqui não funciona assim. Não sei o que vão fazer. O pior é que constroem e depois as casas ficam vazias, ainda mais o mercado como está, ninguém está comprando nada. Depois ainda querem que a gente venda?!

O Programa Minha Casa Minha Vida que surgiu como proposta de acesso a moradia digna e de qualidade às camadas baixas e em ascensão, se configura como uma política de especulação de capital. O financiamento, ou melhor, colocado, a financeirização da moradia, termo cunhado por Rolnik (2015) é ter acesso a aquilo que é concebido como direito universal, através do consumo.

Paga-se, em altas e longas prestações, não somente para ter onde morar, mas para adquirir outros bens além da casa, por exemplo, saneamento, energia, asfalto e o mais importante deles um lar, paga-se para construir um espaço afetivo, de ligações e memórias. Morar em uma casa é, para nossas interlocutoras, diferente de morar na "minha" casa. O pronome é carregado de sentimentos, forma-se não como noção de propriedade abstrata, mas a partir de uma teia que se inicia com a chegada à imobiliária e a procura por Leide, depois "as simulações", aprovações e provações; escolha do imóvel; esperas e por fim a aquisição, que só é finalmente escriturada quando o imóvel é quitado.

No entanto, apesar de todo viés mercadológico no qual o programa foi construído, ele é considerado por seus usurários uma "roubada muito boa", pois é a única forma possível para "os pobres" saírem do aluguel e comprarem a casa própria.

Buscamos através da história de Leide, Eliene e suas clientes compreender um pouco dos processos de financeirização e as burocracias empregadas no programa Programa Minha Casa Minha Vida. O serviço que Leide presta a seus clientes vai muito além da venda, ela busca torná-los dignos de receber o benefício do governo por meio das comprovações exi gidas pela CEF.

Podemos observar em meio a este processo de "ação política" de Leide e suas clientes a geração de vidas a partir dos processos, Leide é capaz de tornar aquilo que é virtual em real. Podemos pensar a gestação dessas "vidas", tendo como concepção a simulação, que requer a escolha de diversos papéis mágicos, não qualquer papel, que se 
transformarão em um dossiê virtual, uma espécie "avatar", que culminará no financiamento e por fim no objetivo final e real a casa, habitação de diversas vidas.

Os trinta anos de prestações (quase outra vida) para aquelas que se beneficiaram da política são possíveis anos de árduo trabalho e empenho para no final ter a casa escriturada. Para elas é melhor pagar 360 meses de prestação e estar morando no que é "seu" do que pagar 360 meses e não ter uma casa. Estar presente naquilo que é delas compensa o longo financiamento e os altos juros.

Trabalhar com Leide nos mostrou os esforços empreendidos por aqueles que desejam sair do aluguel e morar "no que é seu", morar sem correr riscos de despejo, construir uma vida segura em um lar. Ver de "perto" a seleção de documentos e provações as quais Leide e suas clientes necessitam enfrentar para conquista da casa própria nos abrem os olhos para um mercado de exploração que é a única saída para quem não tem condições de adquirir um imóvel.

Escolhi trazer para perto as histórias de Leide e Eliene por acreditar que elas nos falam sobre a vida de muitas pessoas que financiam uma casa pelo PMCMV. A etnografia não como método, mas como forma de produção de teoria, para parafrasear Peirano (2014), é capaz de nos fazer compreender a complexidade, não que a complexidade se faça compreensível, mas talvez visualizar alguns aspectos das realidades por um viés empático e menos como dado. 


\section{Bibliografia}

AMORE, C.S. "Minha Casa Minha Vida" para iniciantes. In: Minha casa... e a cidade? avaliação do programa minha casa minha vida em seis estados brasileiros / org. Caio Santo Amore , Lúcia Zanin Shimbo , Maria Beatriz Cruz Rufino. - 1. ed. - Rio de Janeiro : Letra Capital, 2015.

ARAGÃ̃, D. L. L. J. de; HIROTA, E. H. Sistematização de requisitos do usuário com o uso da Casa da Qualidade do QFD na etapa de concepção de unidades habitacionais de interesse social no âmbito do Programa Minha Casa, Minha Vida. Ambiente Construído, Porto Alegre, v. 16, n. 4, p. 271-191, out./dez. 2016. ISSN 1678-8621 Associação Nacional de Tecnologia do Ambiente Construído. http://dx.doi.org/10.1590/s1678-86212016000400118

BÄHRE, E. Money and Violence: financial self-help groups in a South African township. Leiden and Boston MA: Brill, 2007.

BORGES, A. M. "Tempo de Brasília: etnografando lugares-eventos da política." Relume Dumará, 2003. 194 p.

BACHTOLD, I. V. "Precisamos encontrá-los!" Etnografia dos números do Cadastro Único e dos cruzamentos de base de dados do governo federal brasileiro- Departamento de Antropologia, Instituto de Ciências Sociais, Universidade de Brasília, Brasília- DF, 2017. 167 p.

BONDUKI, N.G. "Origens da habitação social no Brasil". Análise Social vol. xxix (127), $1994\left(3 .^{\circ}\right), 711-732$

GONÇALVES JUNIOR, C. A.; DUTRA, R. de L.; LOPES, R. L.; RODRIGUES, R. L. O impacto do Programa Minha Casa, Minha Vida na economia brasileira: uma análise de insumo-produto.Ambiente Construído, Porto Alegre, v. 14, n. 1, p. 177-189, jan./mar. 2014. ISSN 1678-8621 Associação Nacional de Tecnologia do Ambiente Cons truído.

GUPTA, A. Red Tape: Bureaucracy, Structural Violence, and Poverty in India. Duke University Press Books; 2012 edition (July 17, 2012). 384p. 
HIRATA, F. "Minha casa Minha vida": política habitacional e de geração de emprego ou aprofundamento da segregação urbana?. Aurora ano III número 4, Jul ho de 2009

KLINTOWITZ, D. Por que o Programa Minha Casa Minha Vida só poderia acontecer em um governo petista? Cad. Metrop., São Paulo, v. 18, n. 35, pp. 165-190, abr 2016

KOPPER, M. "Minha Casa, Minha Vida": experts, sentidos de classe e a invenção do "mercado" da casa própria no Brasil contemporâneo. Horiz. antropol. [online]. 2016, vol.22, n.45, pp.185-215.

LATOUR, B. "Não congelarás a imagem", ou: como não desentender o debate ciênciareligião. Mana, Rio de Janeiro , v. 10, n. 2, p. 349-375, Oct. 2004 . Available from $<$ http://www.scielo.br/scielo.php?script=sci_arttext\&pid=S0104-

93132004000200005\&lng=en\&nrm=iso>.

MAUSS, M. "Noção de Pessoa". in "Sociologia Antropologia".Marcel Mauss 2a Edição São Paulo. Cosac Naify, 2015.

MELLO, W. F. " A ditadura, a questão da moradia e a modernização excludente: Roberto Campos em defesa do Sistema Financeiro da Habitação" in Anáis do XVI Encontro Regional de história do Anpuh- Rio: saberes e práticas científicas. Rio de Janeiro 2014.

MOTTA, Luana Dias. [2011] A questão da habitação no Brasil: Políticas Públicas, conflitos urbanos e o direito à cidade.

NASCIMENTO, D.M. As políticas habitacionais e as ocupações urbanas: dissenso na cidade. Cad. Metrop., São Paulo, v. 18, n. 35, pp. 145-164, abr 2016

PATRIOTA DE MOURA,C. «O urbano e suas múltiplas dimensões », Anuário Antropológico [Online], II | 2013, posto online no dia 01 Fevereiro 2014, consultado nodia 06 Dezembro 2016. URL : http://aa.revues.org/510 ; DOI : 10.4000/aa.510vv "Condomínios no Brasil Central. Expansão Urbana e Antropologia". Brasília: Letras Livres/ Editora UnB. 2012 
PATERNIANI, S. Z.. Política, fabulação e a ocupação Mauá: etnografia de uma experiência. 2013. 230 p. Dissertação (mestrado) - Universidade Estadual de Campinas, Instituto de Filosofia e Ciências Humanas, Campinas, SP. Disponível em: <http://www.bibliotecadigital.unicamp.br/document/?code=000907850>.

PEIRANO, M. Etnografia não é método. Horiz. antropol., Porto Alegre, v. 20, n. 42, p. 377-391, Dec. 2014 .

Available from <http://www.scielo.br/scielo.php?script=sci_arttext\&pid=S0104$71832014000200015 \& \operatorname{lng}=e n \& n r m=i s o>$.

. O paradoxo dos documentos de identidade: relato de uma experiência nos Estados Unidos. Horiz. antropol., Dez 2009, vol.15, no.32, p.53-80. ISSN 0104-7183

RODRIGUES, L.P.D; MOREIRA, V.S. Habitação e políticas públicas: o que se te m pesquisado a respeito? urbe. Revista Brasileira de Gestão Urbana (BrazilianJournalofUrban Management), 2016 maio/ago., 8(2), 167-180

ROLNIK, R. Guerra dos lugares: a colonização da terra e da moradia na era das finanças. 1. ed. São Paulo: Boitempo, 2015.

RUFINO, M. B C. Transformação da periferia e novas formas de desigualdades nas metrópoles brasileiras: um olhar sobre as mudanças na produção habitacional. Cad. Metrop., São Paulo, v. 18, n. 35, pp. 217-236, abr 2016

SILVA, M. C. A. Entre as estatísticas e a cidade: o cadastramento e a produção da demanda social por apartamentos, no Programa Minha Casa Minha Vida. Cad. Metrop., São Paulo, v. 18, n. 35, pp. 237-256, abr 2016

SOBRAL, J. R. Comissiologia no Castelo da Educação Escolar Indígena (2018) Dissertação (mestrado)- Departamento de Antropologia, Instituto de Ciências Socias, Universidade de Brasília, Brasília- DF, 2018.

VICENTIN, T. N.; KANASHIRO, M. Análise do comércio e dos serviços nos empreendimentos do Programa Minha Casa, Minha Vida (PMCMV): estudo de caso do Residencial Vista Bela - Londrina, PR. Ambiente Construído, Porto Alegre, v. 16, n. 4, p. 227-250, out./dez. 2016 